\title{
اختطاف الرهائن البشرية وموقف الإسلام منه
}

\section{دكتور : عبد الولى بن مشعان السلمى}

استاذ مشارك بقسم الدراسات الاسلامية والمهارات اللغوية كلية العلوم والاداب بالكامل المملكة العربية السعودية

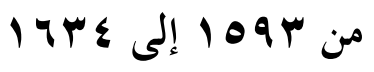


1098 


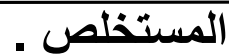

لقد اهتمت الاراسة ببحث ماهية اختطاف الرهائن ، وضوابط الاختطاف

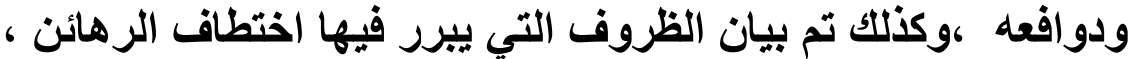

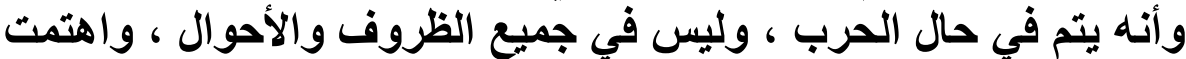

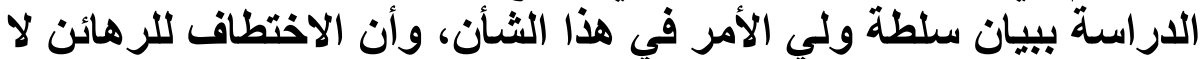

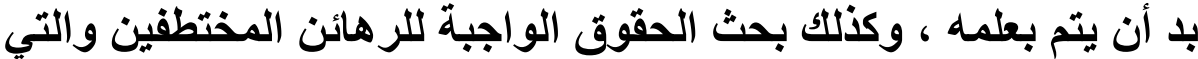

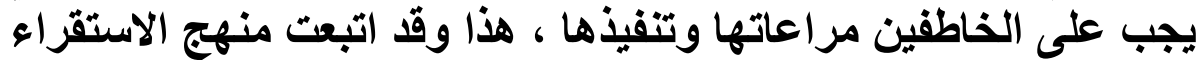

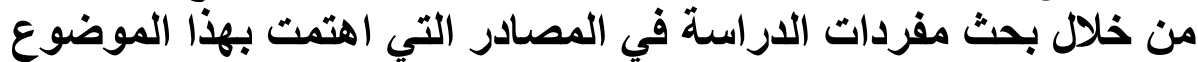

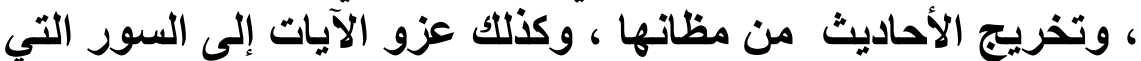

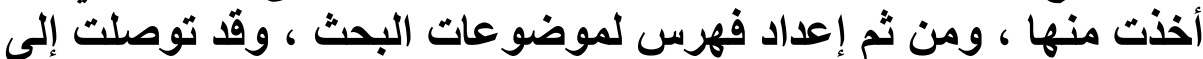

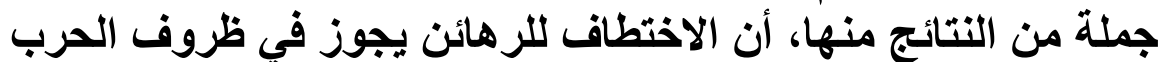

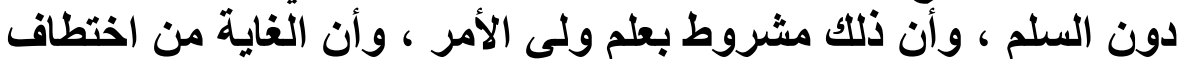

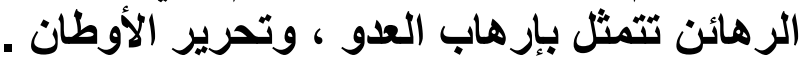

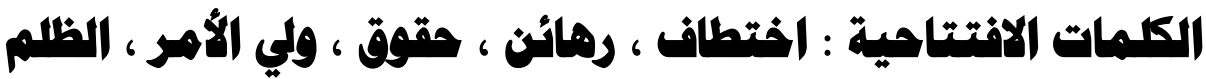
Abstract

The study focused on examining the nature of hostage-taking, its constraints and motives as well as the circumstances justifying this act, particularly in the event of war and not in other situations. The study also focused on the guardian's authority in this regard, and that any act of hostage-taking should not take place without his full knowledge. Also, the survey examined the due rights of the hostages abducted which the kidnappers must observe and implement. Accordingly, induction approach has been followed by this research in examining the terms of the study in the sources that had been interested in this field, quoting Hadiths (prophet's sayings), and attaching each verse to its Surah (chapter in the holy Koran); Then prepare a table of contents of the 
research paper. I have reached a number of conclusions, including the kidnapping of the hostages may be in conditions of war not peace, with the knowledge of the guardian as a condition; and that the motive behind the act of hostage-taking is to terrorize the enemy and liberate nations. 


\section{الآله الرحمن الرحيم}

مقدمة:

الحمد الله رب العالمين، والصـلاة والسـلام على معلم النـاس الخيز،

وهادي البشرية إلى الرشد، الذي بين أن منـاط خيريـة الإنسـان عند الله

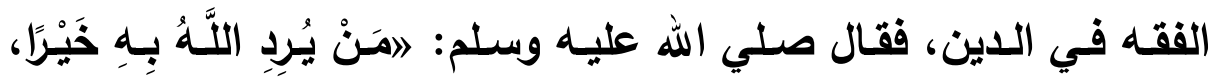

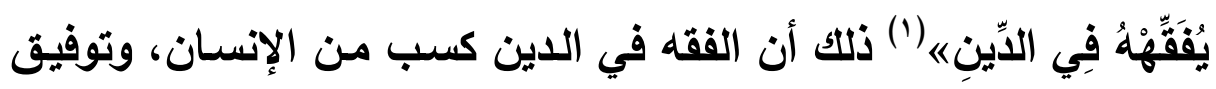
واصطفاء مسن الله، وعلى آلـه وأصـحابه ومسن تبعهم بإحسـان إلسي يـوم

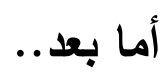

فلا شك أن الإسلام في تأطيره لسلوك الفرد في حالة الاعتراض أو الاحتجـاج أو المطالبـة بمطالب مشـروعة؛ إنمـا جعل اختطساف واحتجـاز الرهائن منحصرا في حالتي الحرب ،أو نقض العدو للسـلام؛ لا سيما أنها قد حوى ،وضمن أرقى ما يمكن أن تصل إليه الإنسانية من طرائق التعبيز

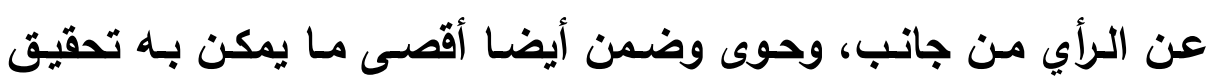
الأمن والسكينة للأفراد ،والجماعات من جاتب آخر؛ ولذلك فإن الإسـلام يرفض هذا السلوك إلا بضوابطه التي نسجتها الشريعة الإسلامية ،ويرمسي هذا البحث إلى بيانها.

(') صحيح البخاري ، للبخاري كتاب العلم، باب: من يرد الله بـه خيرًا، ا9V/ 19 وفي كتاب

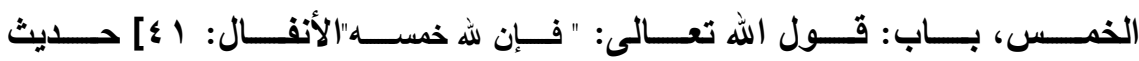

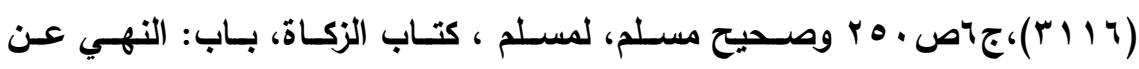

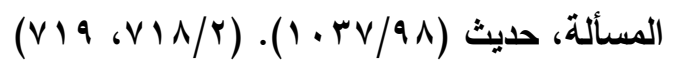




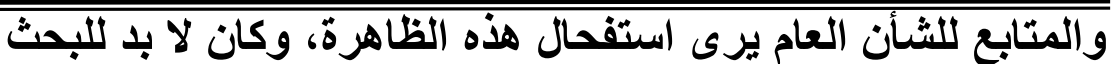

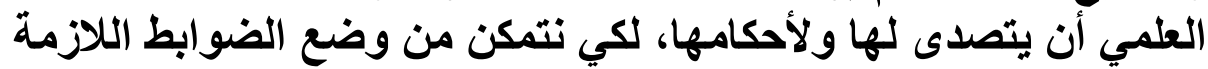

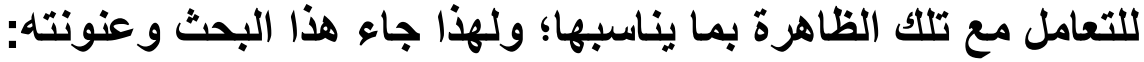
״اختطاف الرهائن البشرية وموقف الإسلام منهاه.

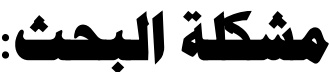

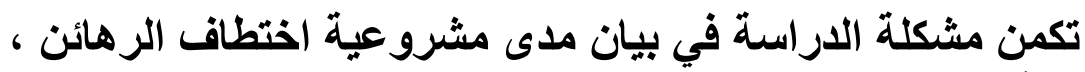

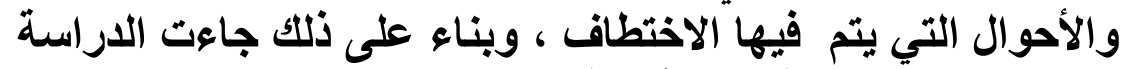

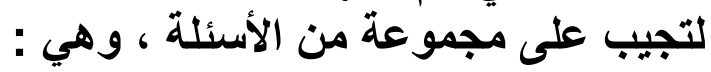

ا - ما مفهوم اختطاف الرهائن في اصطلاح العلماء ؟ r - ما الضوابط التي يجب التزامها عند اختطاف الرهائن ؟ ب- با الدوافع التي تستدعي اختطاف الرهائن ؟ ع - هل يشترط علم ولي الأمر عند الاختطاف ؟ لأني ه- ما الحقوق التي أقرها الإسلام للرهائن ؟

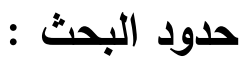

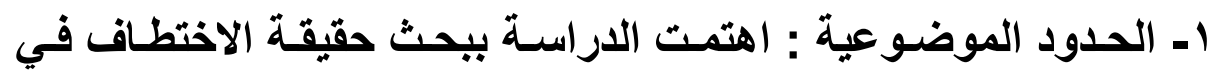

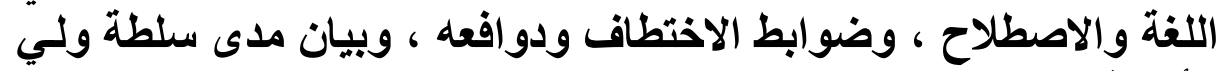
الأمر فيما يتطق بعلمه بالاختطاف ، وبحث حقوق الرهائن ودلى على الخاطفين

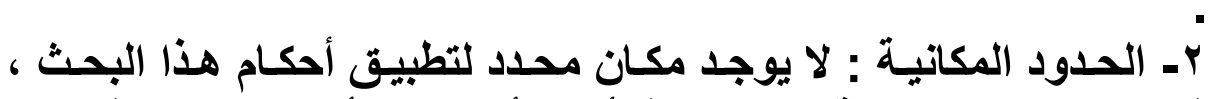

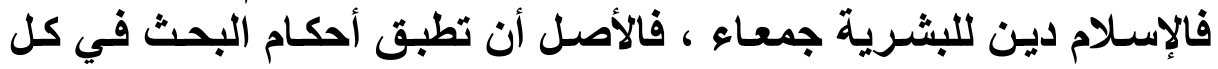

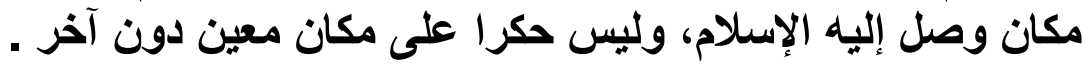

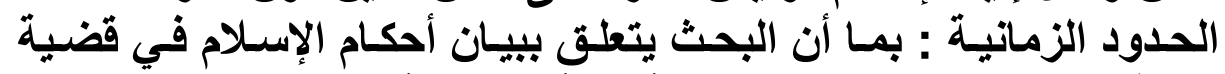

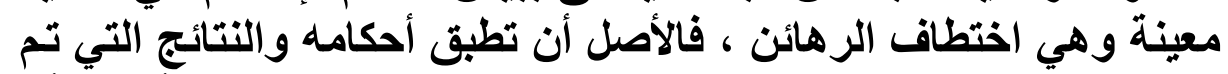

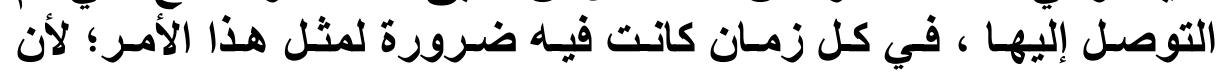

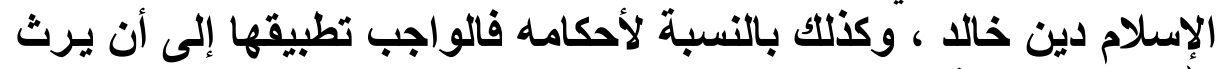
الله عز وجل الأرض ومن عليها. 


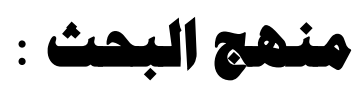

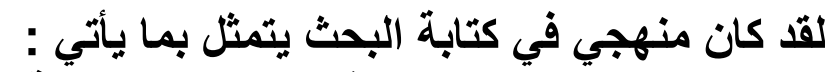

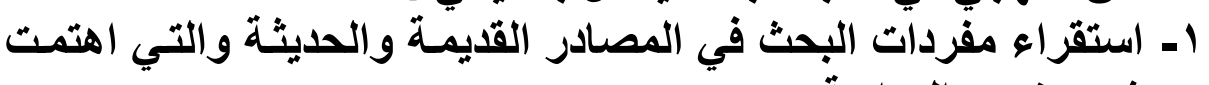

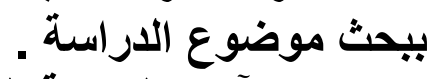

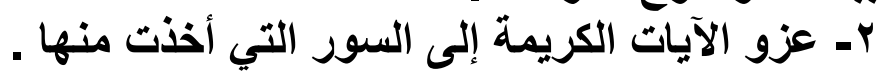

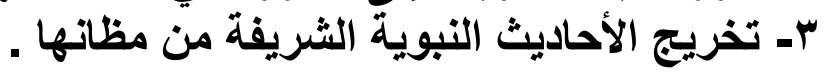

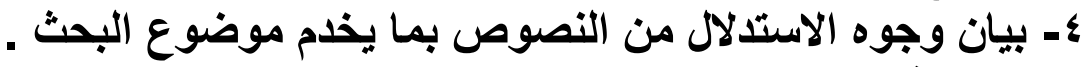

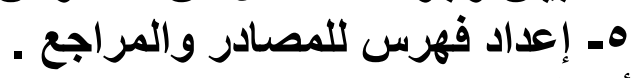

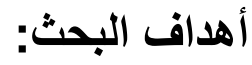
تتمثل أهداف الاراسة فيما يأتي :

1 - بيان حقيقة اختطاف الرهائن في اللغة والاصطلاح .

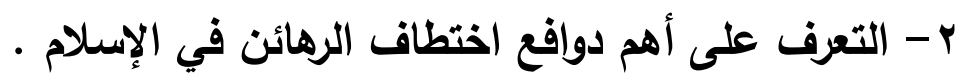
r - توضيح ضوابط اختطاف الرهائن في الإسلام . ع - بيان الحقوق التي أقرها الإسلام للرهائن .

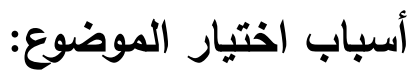

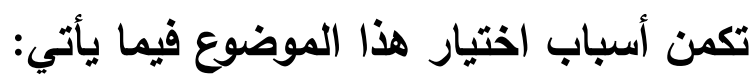
1 - من أجل بيان التأصيل الثرعي لاختطاف وإحتجاز الرهائن في الفقه الإسلامي ومدى مشروعيتها، ودوافعها.

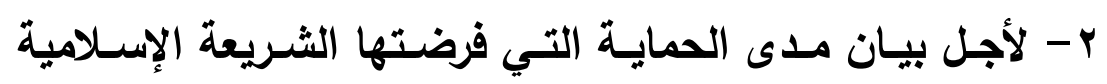
ورعايتها للرهائن.

ب- لبيـان عظمـة الشـريعة الإسـلامية وتفوقهـا وسـبقها لسـائر

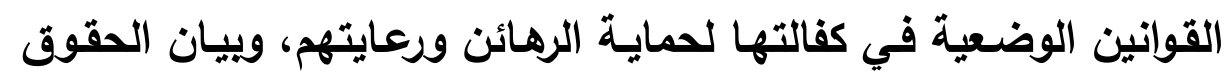

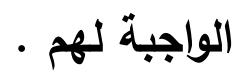


؟ - من أجل التببيه على خطورة المغالاة ، والبعد عن الضوابط

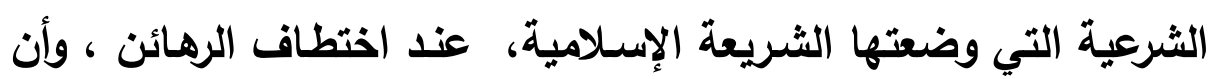
الأمر ليس على إطلاقه .

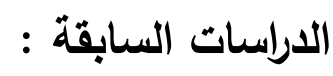

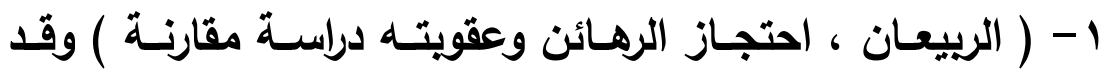

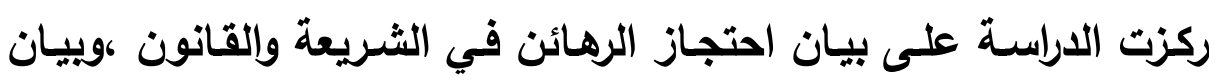

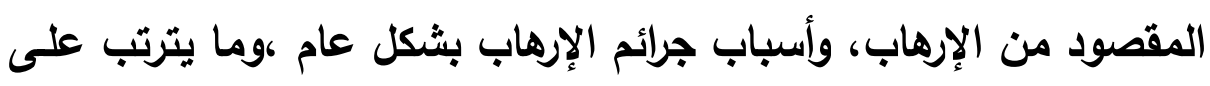

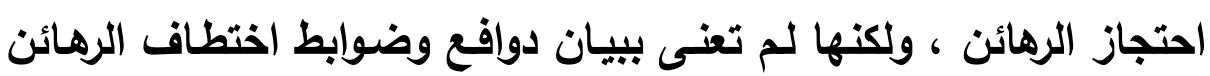

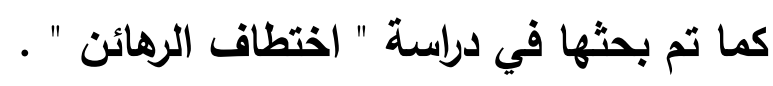
r - ( مجلس حقوق الإنسان ، حقوق الإنسان والمسائل المتعلقة

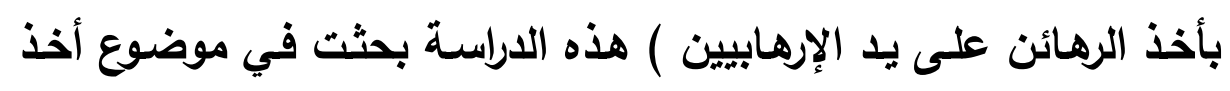

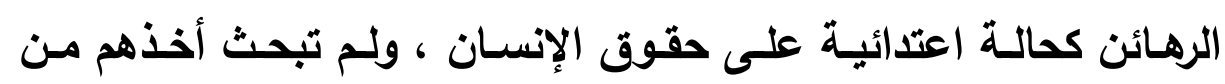
ناحية شرعية وذلك في حال وجود الدوافع لاختطاف الرهائن ، وكذلك لـ لم المان

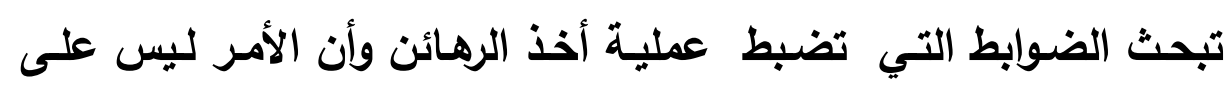
إطلاقه ، وذلك كما تم بحثه في دراسة " اختطاف الرهائن " . خطة البحث.

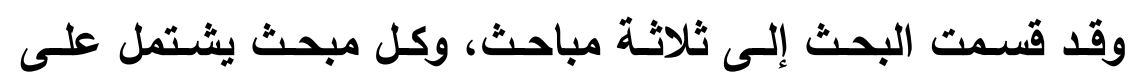
مطالب ، وخاتمة في نهاية البحث على النحو الآتي:

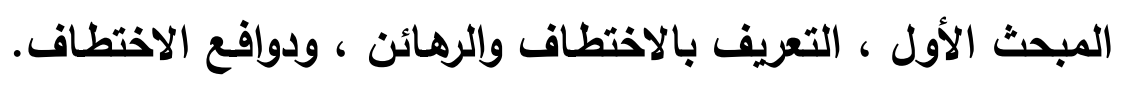

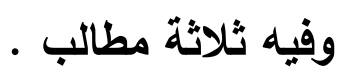

المطلب الأول : تعريف الاختطاف لغة واصطلاحاً. المطلب الثاني :تعريف الرهائن لغة وإصطلاحاً. 
المطلب الثالث : حكم اختطاف الرهائن .

المبحث الثاني: ضوابط اختطاف الرهائن في الفقه الإسلامي.

وفيه ثثلاثة مطالب:

المطلب الأول: اشتراط تحقق العدوان.

المطلب الثاني: علم ولي الأمر بعملية الاختطاف.

المطلب الثالث: سلامة المقصد في عملية الاختطاف.

المبحث الثالث : حقوق الرهائن .

الخاتمةة: وتثتثمل على أهم النتائج والتوصيات . 
.

\section{ودوافعه}

حتى نقف على تحديد مدلول اختطاف الرهائن البشرية في الفقه الإسلامي لا بـ من تحديا ماهيته لغة وإططلاحا. المطلب الأول: تعريف الاختطاف لغة واصطلاحا:

الاختطاف: اسم مشتق من المصدر (خطف) ويطلق في اللغة على معسان منهـا: أخــ الثـيء بسـرعة واستتلابه، يقـال خطف الثـيء، أي :

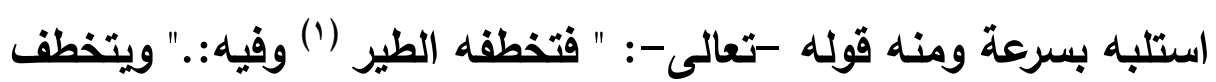
النـاس مـن حولهم.. "(ז) واختطف الثـيء أي: اجتذبـه، وخطف السـمع

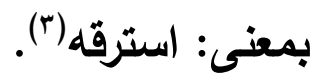
ويـأتي الاختطاف بمعنى 》الاختلاسه، فيقال للص الذي يختلس الشيء: خطاف، وتطلق الخِطفة - بالكسر - على المرة الواحدة(؛).

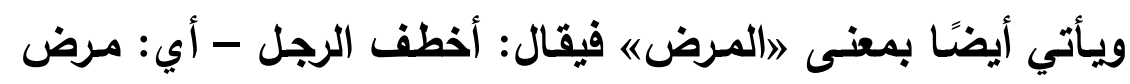

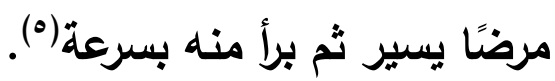

$$
\begin{aligned}
& \text { (') سورة الحج، الآية: اسب. }
\end{aligned}
$$

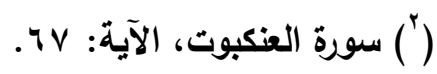

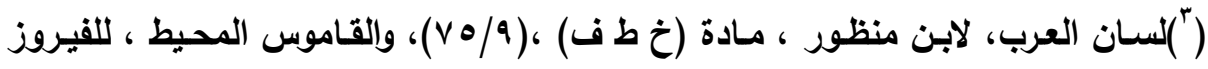

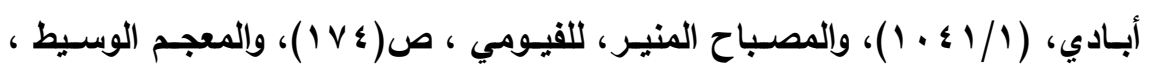

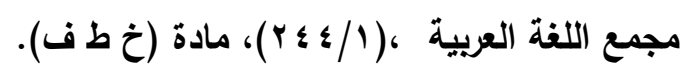

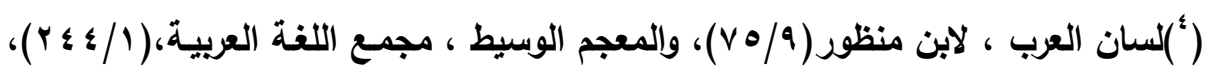
مادة (خطف).

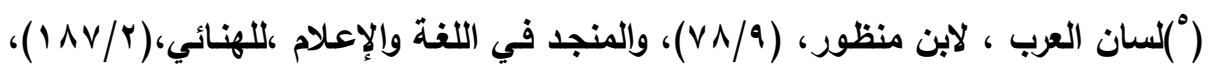

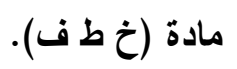


فـالخطف في اللغـة يطلق ويـراد في المعنى العـام الأخذ بسـرعة، والاختطاف هو: الإغارة والاستيلاء على الأشخاص وأسرهم. تعريف الاختطاف اصطلاحًا:

ليس للفقهاء القدامى تعريف لمفهوم الاختطاف بمعنـاه الحديث؛ ويرجـع ذلك لحداثة هذا المفهوم؛ حيـث لـم يكن معروفًا عند الفقهاء السابقين بهذا الاسم، لاوإن كان بعض الفقهاء قد توسـع في مفهوم حد الحرابة فجعله شاملًا لكل أنواع الجرائم التي تقع في الطريق سواء وقعت بقصد سلب المال، أو الاعتداء على الأثخاص بالقتل أو انتهاك العرض أو حتى مجرد جرائم الإخافة والإرعاب(' أل. وهنا لا بـ من الإثارة إلى العلاقة بين الحرابة ، واختطاف الرهائن ، الرهاب وذلك أن كلاهما يكون في ظروف غير عادية ، ويحدث الرعب في قلوب الآخرين ، فالاختطاف لا يكون في حالة السلم ، وإن حصل فهو جريمـة من أعظم الجرائم التي ترتكب بحق الآمنين ويالنسبة للحرابـة وإن اتفقت مـع الاختطاف في بعض الجوانب التي أشرث إليها ، إلا أنها تعد أعم من الاختطاف وذلك بـالنظر للأعمال التي يقوم بها المحاريون ، والتي

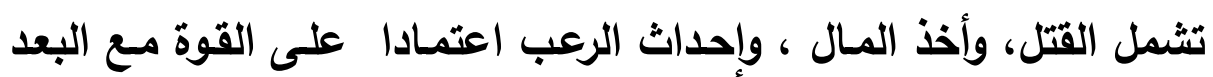
عن الغوث (r). (ب) تعريف اختطاف الرهائن في الاتفاقيات الدولية .

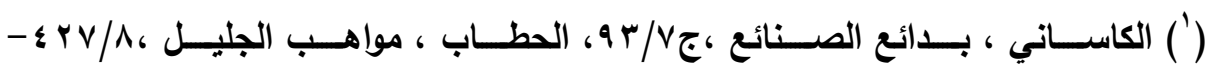

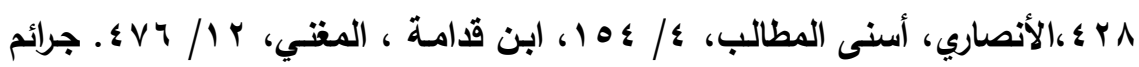
الاختطاف، لعبد الوهاب المعمري، ص( • ؛ ).

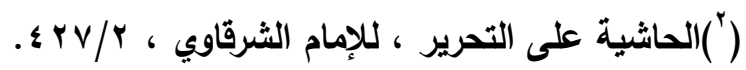


ورد تعريـف اختطـاف الرهـائن في الاتفاقيـات الاوليـة بأنـهـه : أي شخص يقبض على شخص آخر أو يحتجزه ويهدد بقتله ، أو إيذائهه ، أو

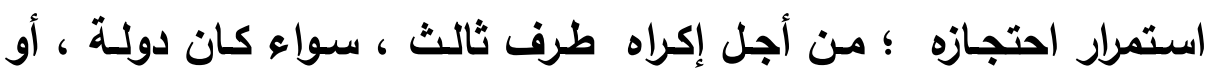

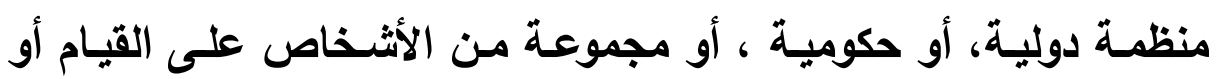

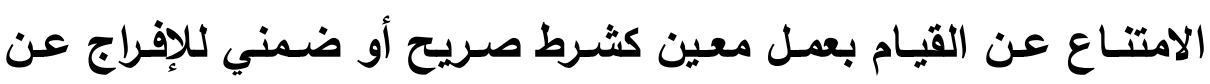

الرهينة (') (1)

وعلى هذا فالاختطاف يمكن أن يعرف بأنه: الاستيلاء على شخص

ما، ولا يمكن تحريره إلا بتلبية مطالب من استولى عليه . المطلب الثاني: تعريف الرهائن لغة واصطلاحا: تعريف الرهائن لغة: الرهن لغة: يعني الحبس (ז)، قال تعالى:(( كل امرئ بمـا كسب رهين (r) $(($

أي محتبس بعمله، وقوله تعالى (( كل نفس بما كسبت رهينه )) (؛)

$$
\text { أي محبوسة بكسبها }
$$

قال الفيروزأبادي: اولمّا كان الرَّهْن يُتصوّر منه حَبْسه استعير ذلك للمحتبِس أَيّ شيعٍ كان، قال تعالى :" كل امرئ بما كسب رهين" (•) (").

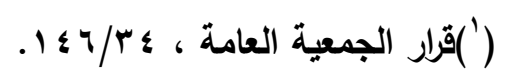

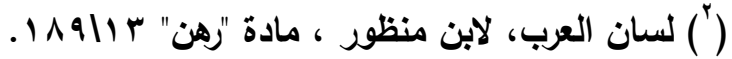

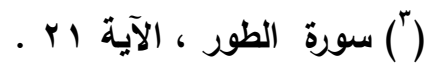

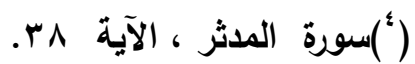

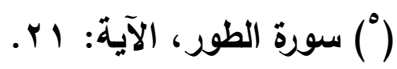

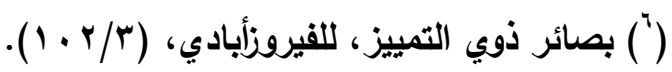


تعريـف الرهـائن في اصطلاح العلمـاء المعاصرين ، والاتفاقيـات

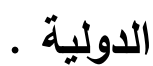

هذا وقد تحدث الفقهاء السابقون عن الأسرى ومـا يتعلق بهم من أحكام ، أمسا الرهائن فهو مصطلح حديث ، وهذا مـا دفعني للقيام بيحث مفهوم هذا المصطلح عند العلمـاء المعاصرين ،ومـن خلال البحث فقد توصلت إلى أن العلماء المعاصرين عرفوا الرهائن بأنهر : الأثخاص الذين يتم خطفهم واحتجازهم، والتهديد بقتلهم ، واستمرار احتجازهم ؛ من أجل إكراه طرف آخر على القيام، أو الامتناع عن عن القيام

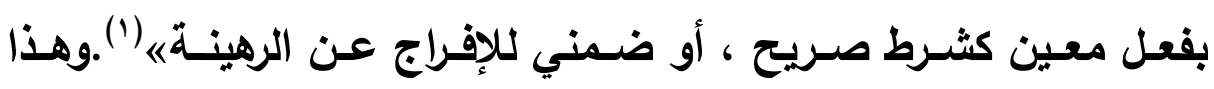

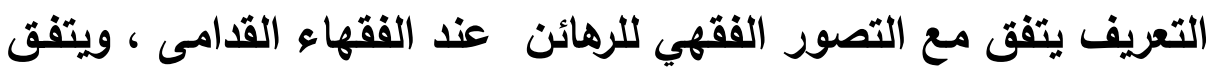

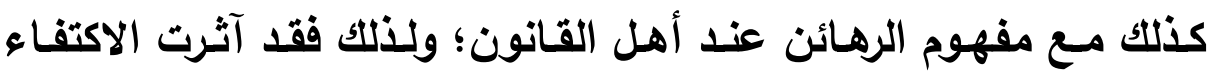
بتعريف العلماء المعاصرين ،والاتفاقيات الاولية ؛ تجنبا للإطالة . المطاب الثالث : مكم اختطاف الرهائن.

من خلال البحث في أحكام الأسرى في الإسلام نجد بأنها يجوز أخذ الخد

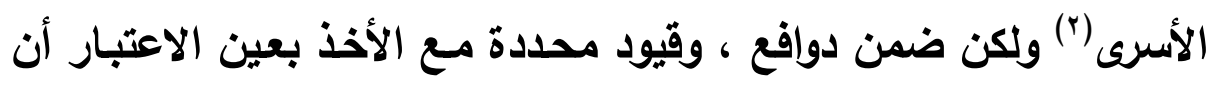

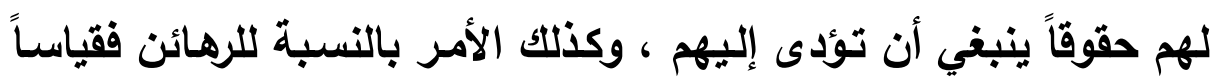

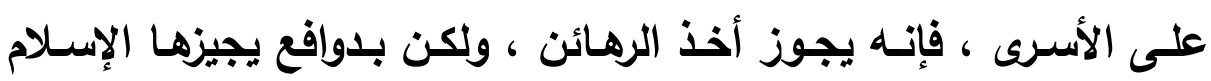

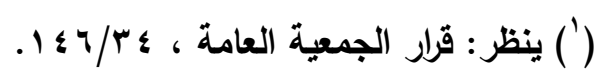

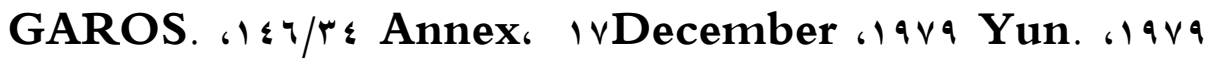

$$
\text { P. . II } 1 \leqslant
$$

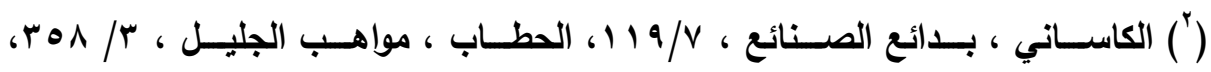

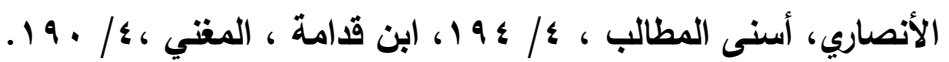




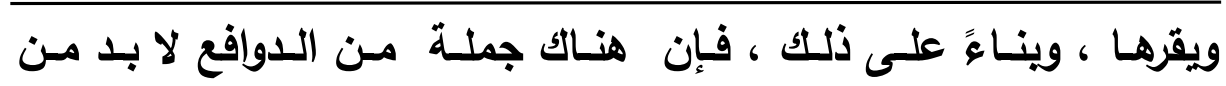

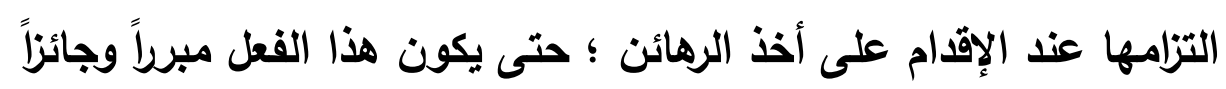

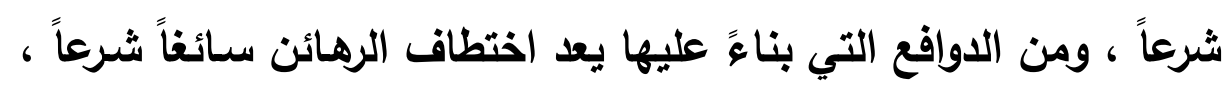
من ذلك :

1- إرهاب العدو ومنعه من العدوان أو التمادي فيه(1)

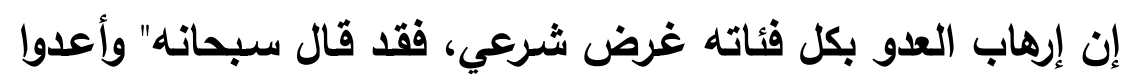

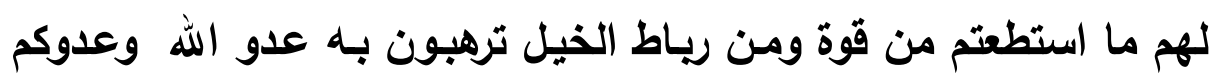

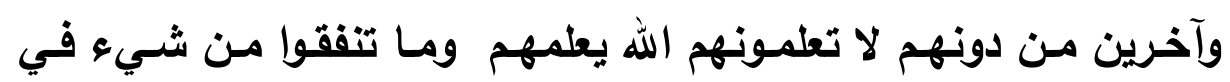

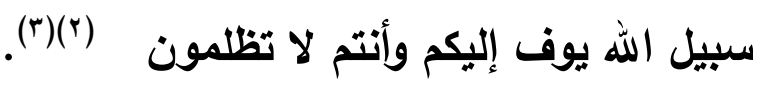

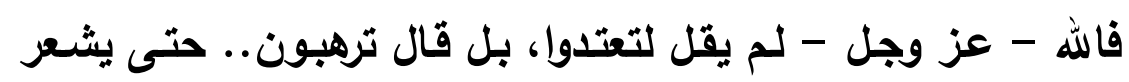

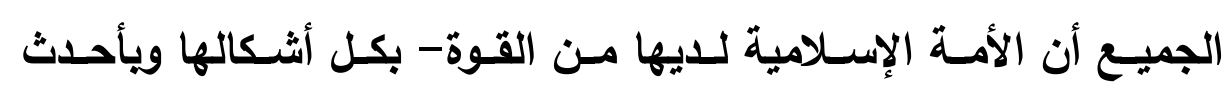
وسائلها- ما تستطيع به أن تصدَّ أي عدوان يوجَّه إليها.

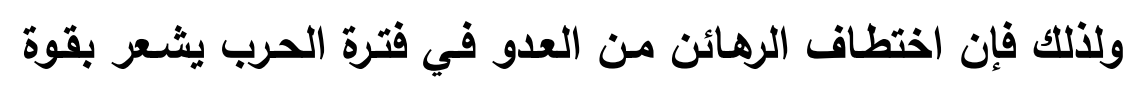

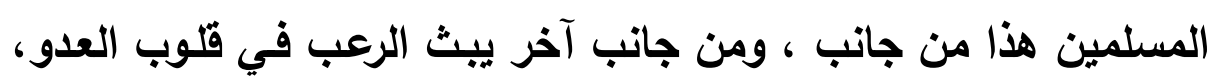

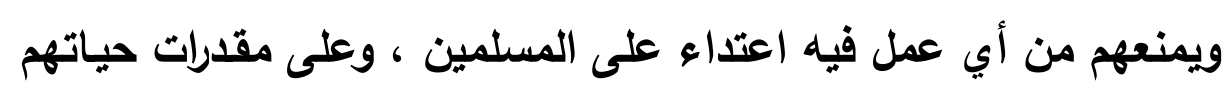

(') تسليط الأضواء على ما وقع في الجهاد من أخطاء، لأسامة إبراهيم حافظ، عاصم عبد

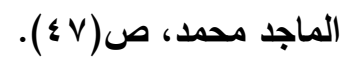

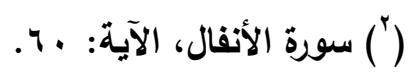

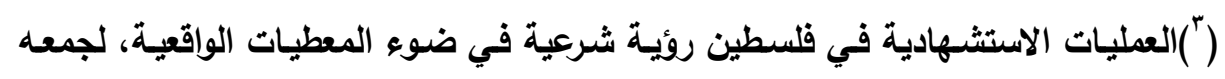

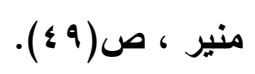




$$
\text { r - الكفاح من أجل تحرير الأوطان(') }
$$

من دوافع الاختطاف رد العدوان عن استباحة الأوطان، وقد أمر الله بذلك في كتابه الكريم، ومن ذلك : الانطاف رد العان 1- قوله تعالى:" وقاتلوا في سبيل الله الذين يقاتلونكم ولا تعتدوا

قال القرطبي" : اوالصحيح أنه خطاب لجميع المسلمين، أمر كل

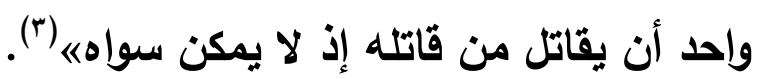

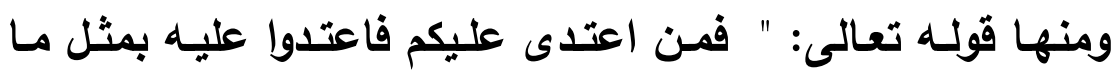
اعتدى عليكم(أ). أي: اردوا عن أنفسكم العدوان، فمـن قـاتلكم في الحسرم، أو في

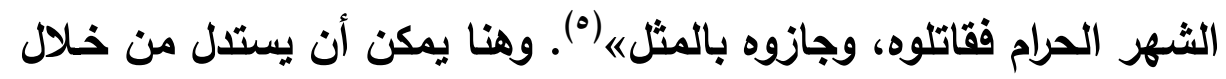

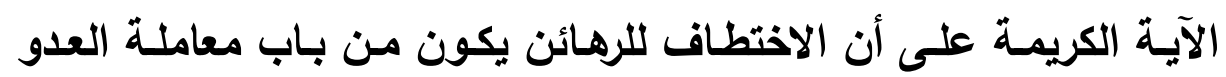

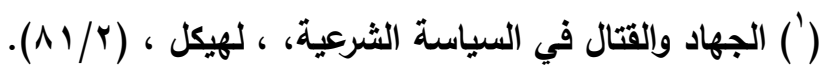

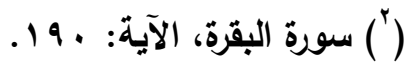

• القرطبي : أبو عبد الله محمد بن أحمد بن أبي بكر الأنصاري القرطبي

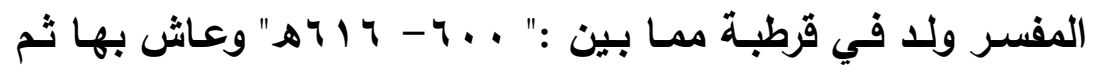

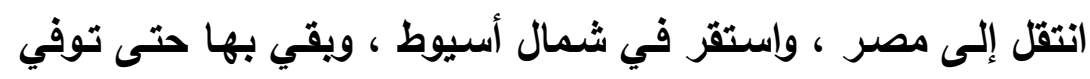

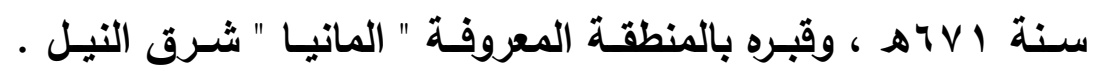

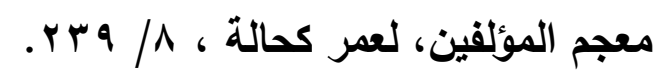

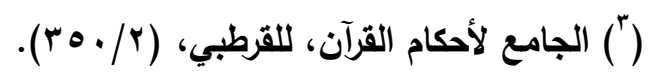

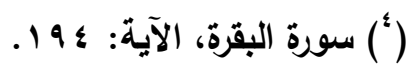

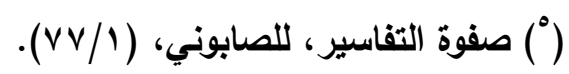




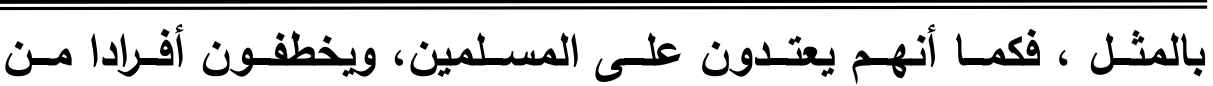

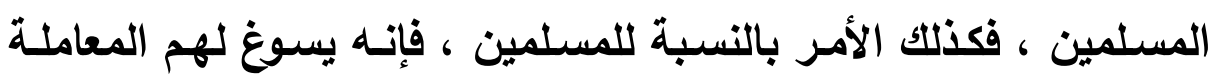

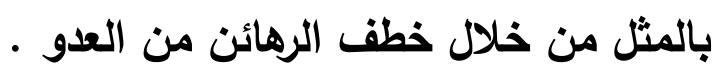

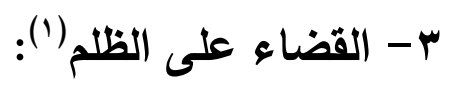

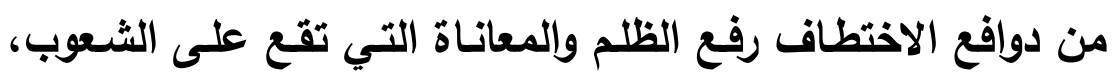

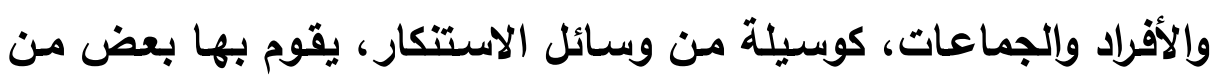
لحقهم الظلم، ليعبروا عما هو داخل نفوسهم من جراء هذا الظلم (؟).ودليل ذلك قوله تعالى :" أذن للذين يقاتلون بأنهم ظلموا وإن الله على نصل نصرهم

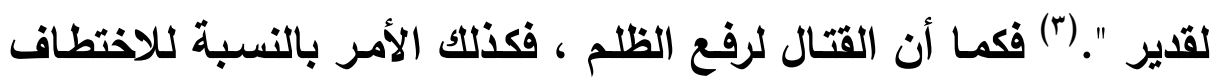
فإنه يكون لرفع الظلم عمن لحقهم .

ع - : تحقيق أهداف إستراتيجية وأمنية(4):

وتعد هذه الأهداف متجددة ، ومتنوعة ميع تطور الآلة العسكرية

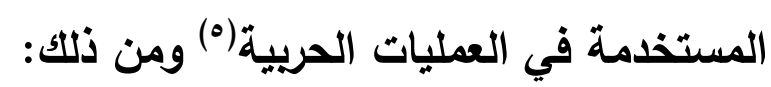
أ- تحقيق نتائج ملموسة بأقل الإمكانات. ب- زعزعة استقزار العدو وتحطيم معنوياته.

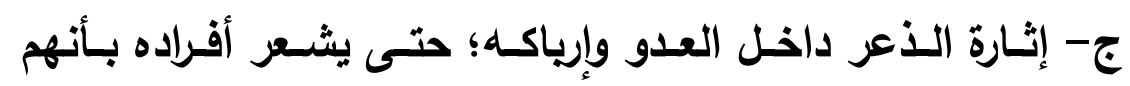
معرضون للقتل.

(') (') أحكام الأسرى والسبايا في الحروب الإسلامية، ، لعبد اللطيف عامر ، ص (1) ).

$$
\begin{aligned}
& \text { (") (") المصدر السابق. } \\
& \text { (") سورة الحج ، الآية : و ج". } \\
& \text { (") (") قضايا فقهية في العلاقات الدولية حال الحرب، لحسن أبو غدة، ، ص(Vv). } \\
& \text { (") }
\end{aligned}
$$


17.9

د- الحصول على معلومات من المختطف من شـأنها الاطلاع على

أهم وسائله والتقتيات التي يمتلكها.

هـ - الضـغط على العدو لفـك أسـرى رعايـا الاولـة الإسـلامية عن لن

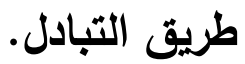




\section{المبمث الثاني:}

\section{ضوابط اختطاف الرهائن في الفقه الإسلاهي.}

بعد بيان الدوافع التي بناءًً عليها يسوغ اختطاف الرهائن ، ارتأيت

بيان جملـة مـن الضـوابط لا بـ من تحققها عند الاختطاف ، حيث إن الأمر ليس على إطلاقه ؛ فتوفر الضوابط عند أخذ الرهائن ممـا يضفي على الأمر صفة الجواز الشرعي • وقد قسمت هذا المبحث إلى ثلاثنة مطالب ، وهي : المطلب الأول: اشتراط تحقق العدوان. المطلب الثاني: علم ولي الأمر بعملية الاختطاف. المطلب الثالث: سلامة المقصد في عملية الاختطاف.

\section{الاكبا الأول: اثشتزاط تمقق المدوان.}

اشـترط الإسـلام لجـواز اتخـاذ الأسـارى مـن أهل الحـرب أن يكون

العدوان متحقةًا بالفعل (1) وقد دل على ذلك الكتاب ، والسنة .

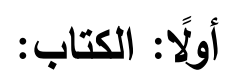

1 - قوله تعالى:" وقاتلوا في سبيل الله الذين يقاتلونكم ولا تعتدوا

قال القرطبي: اوالصحيح أنه خطاب لجميع المسلمين أمر كل واحد

أن يقاتل من قاتله إذ لا يمكن سواهی) (ॅ).

(') مائة سؤال عن الإسلام، للغزالي، الثيخ محمد ص(ب 9).

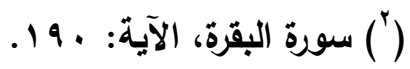

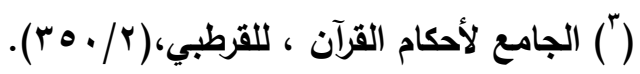


r - قوله تعالى: " فمن اعتدى عليكم فاعتدوا عليه بمثل ما اعتدى

عليكم (1).

أي: اردوا عن أنفسكم العدوان، فمـن قـاتكم في الحـرم، أو في

الثهر الحرام فقاتلوه، وجازوه بالمثله (؟).

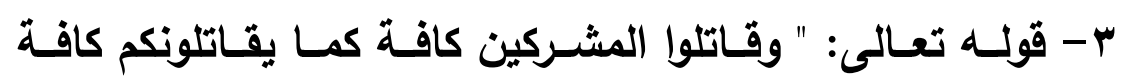

واعلموا أن الله مع المتقين (َّ).

قـال القرطبي (4): قـاتلوا: أمسر بالقتـال، وكافـة معنـاه: جميعًا وهـو الهو

مصدر في موضع الحال ، أي: محيطين بهم ومجتمعين.

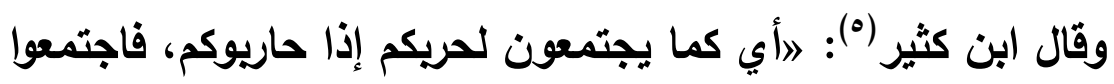

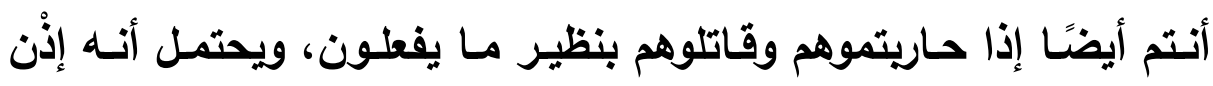

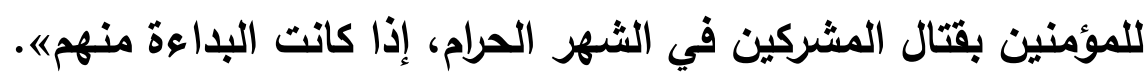

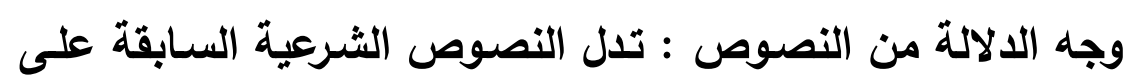

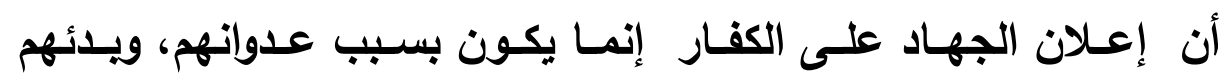

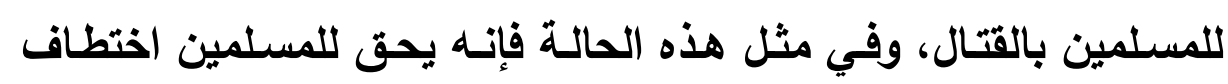

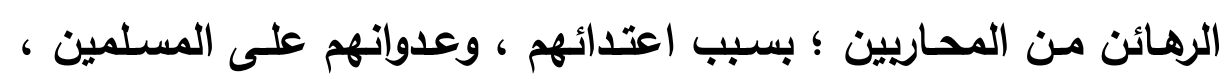

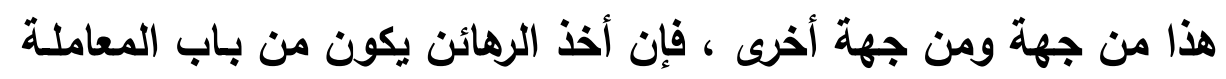

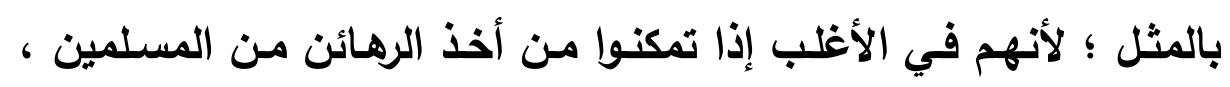

$$
\begin{aligned}
& \text { (') سورة البقرة، الآية: ؛ } 9 \text { ا. }
\end{aligned}
$$

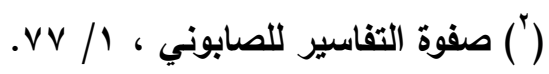

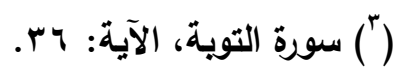

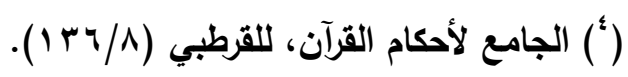

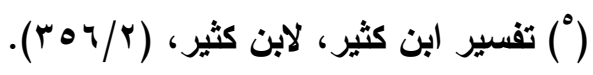




\section{$171 \%$}

فلن يألوا في ذلك جهداً ،وهذا بحد ذاته يعد من أعظم صور، وأشكال

الاعتــاء على المسـلمين ، ولا بــ مـن معـاملتهم بالمثل ؛ مـن أجـل رد

عدوانهم عن المسلمين ، وحفظ كرامة الأمة وهيبتها . 


\section{الإلب الثاني:}

\section{علم ولي الأهر بعملية الاختطاف.}

صسيانة بيضـة الإسـلام، وحمايـة الاولـة الإســلامية، وحفـط أمنهـا

الخارجي - واللاخلمي أيضًا - من واجبات ولـي الأمر، واختصاصـاته التي

لا يجوز للآحاد الافتيات عليه فيها.

فقد ذكر الماوردي أنه يجب على الإمام تحصين الثغور، وجهاد من

عاند الإسلام بعد الاعوة؛ حتى يسلم ، أو ياخل في الأمة'(1).

فعلى ولي الأمسر أن يحفظ أمن البلاد بسد الثغور، وإقامسة الرجال

على المراصد، وإعداد القوة الكافية لإرهاب الأعداء، وقهرهم، ودريع أذاهم عن المسلمين، عملًا بقوله تعالى:"وأعدوا لهم مـا استطعتم من قوة ومن لإن

$$
\text { رياط الخيل ترهبون به عدو وعدوكم" (؟). }
$$

وإذا كانت حمايـة البيضـة، وتـدبير أمـر الجيوش والجنود إلى ولـي الأمر؛ فإن أخص ما يتعلق بذلك هو إعلان الحرب؛ فلا بد أن يكون ذلك إلى ولـي الأمر، ولا يصـح لأحد ألبتـة الافتيـات عليه في ذلك؛ وفي ذلك يقول ابـن قامـة في كتابـه المغني: اوأمسر الجهاد موكـول إلى الإمسام

واجتهاده، ويلزم الرعية طاعته فيما يراه من ذللك)(؟).

(') (الأحكام السلطانية، للماوردي، ص (1) (1).

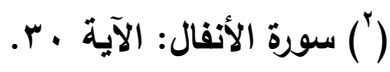

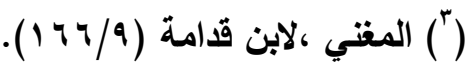


وقال شيخ الإسلام ابن تيمية في منهاج السنة: روالجهاد لا يقوم به

إلا ولاة الأمور)(1).

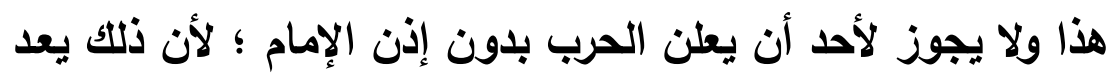

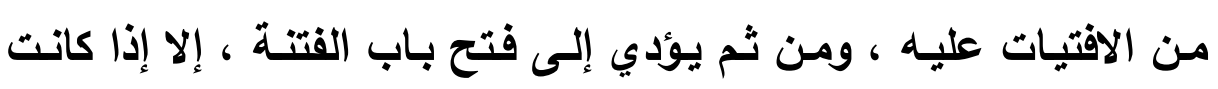

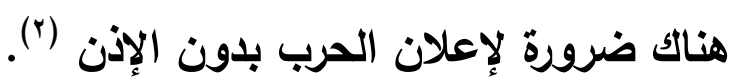

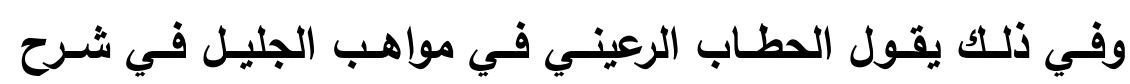

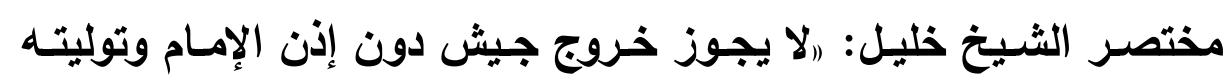

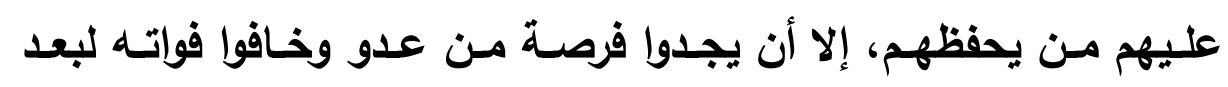

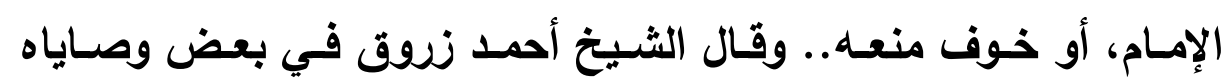
لإخوانه: التوجه للجهاد بغير إذن جماعة المسلمين وسلطانهم: هو سُّلَّم

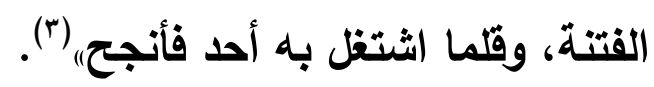
ولكن لا بـ هنا من التنبيه على أمر هام، وهو أن المحظور في أمر أند

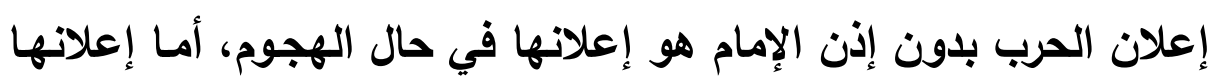

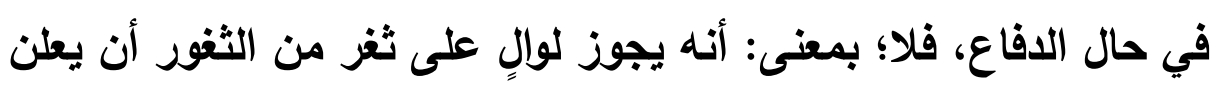

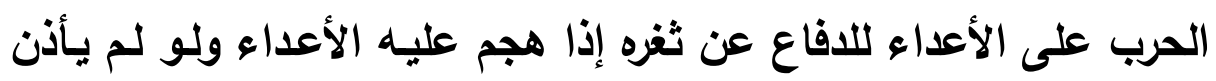

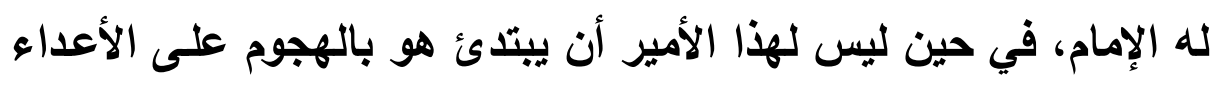

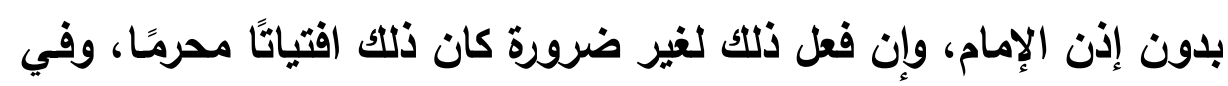

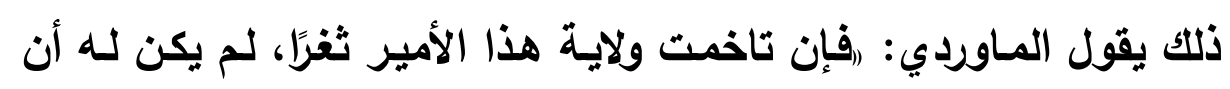

(') (') منهاج السنة النبوية ، لابن تيمية(1/1/4، (1) ).

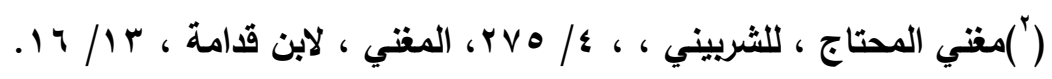

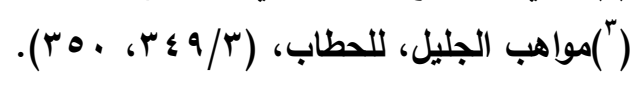


يبتدئ جهاد أهله إلا بإذن الخليفة، وكان عليه حربهم ودفعهم إن هجموا عليـه بغير إذنـهـ لأن دفعهم مـن حقوق الحمايـة ومقتضسى الذب عن

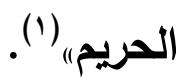

الأدلة على اشتراط علم الإمام بالاختطاف وإذنه لإعلان الحرب . يستدل لعلم الإمام ، وإذنه لإعلان الحرب من السنة بما يأتي : 1 - ما خرجه البخاري ، ومسلم في صحيحيهما من حديث أبي

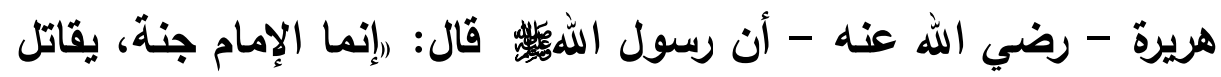

$$
\text { من ورائه ويتقى بها"(r). }
$$

وجه الالالة: الحديث صريح في أن الجهاد يكون تحت رايـة الإمـام؛ بل جعل الإمام بمثابة الستر، والمجن الأي يتقي به المسلمون أعداعهم. وفي ذلك يقول النووي * قوله يمنع العدو من أذى المسلمين، ويمنع الناس بعضهم من بعض، ويحمي بيضة الإسلام، ويتقيه الناس، ويخافون سطوته.

$$
\text { (')('الأحكام السلطانية، للماوردي، ص (r^). }
$$

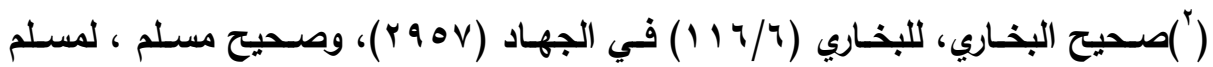

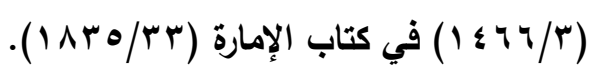

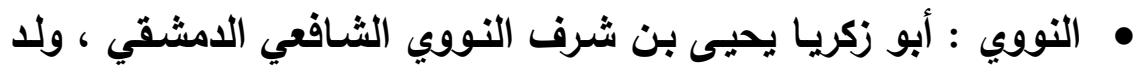

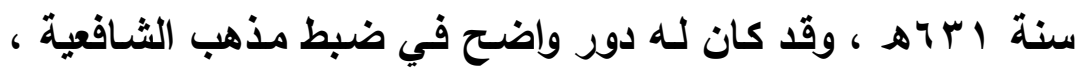

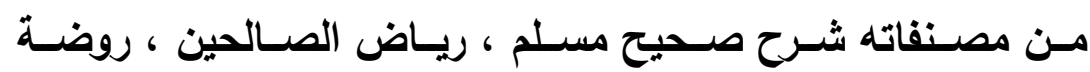

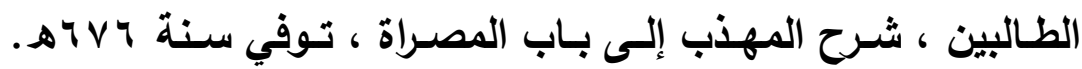

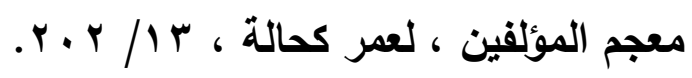


ومعنى قوله

والخوارج وسائر أهل الفساد ، والظلم مطلقًا (1).

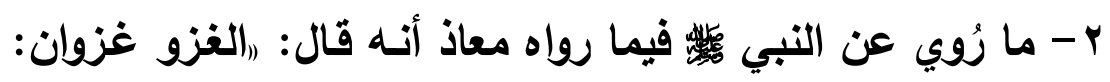

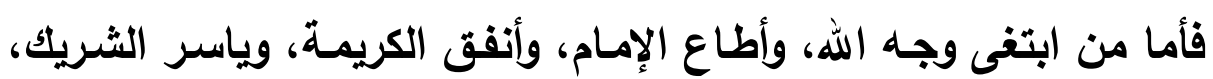

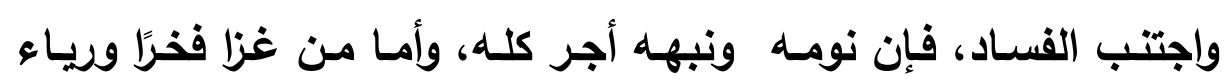

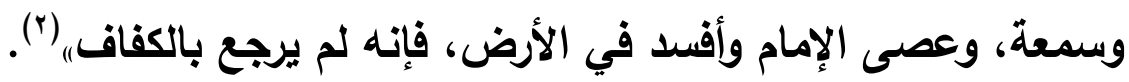

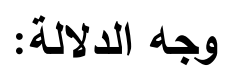

يـلال الحديث على أن الجهاد، والغزو الـذي يستحق بـه الأجر ،

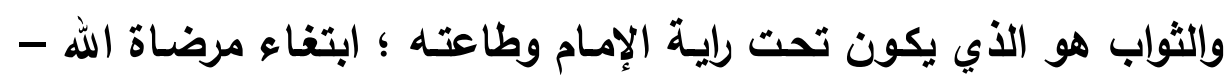
عَزَّ جلَّ.

ومن حقوق ولي الأمر أنه لا يجوز الافتيات عليه في الأسسار، لا بقتل، ولا استرقاق، ولا عقد ذمة، ولا من.

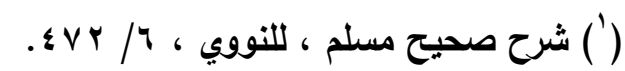

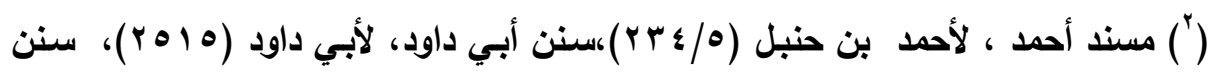

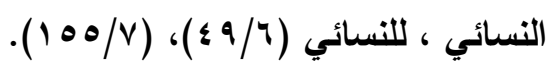

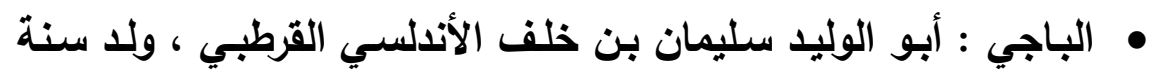

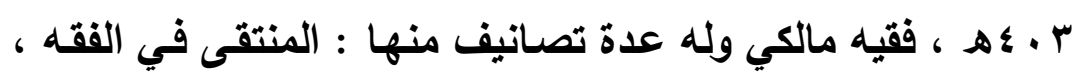

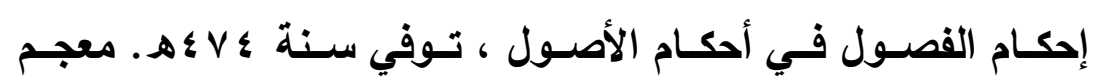

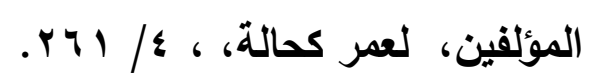


وفي ذلك يقول أبو الوليد الباجي* : (المأسسور أمسره إلى الإمـام،

فليس لغيره الافتيات عليه فيه، كما أنه ليس لغير الإمام استرقاقه، ولا عقد الأمة له؛ كذلك ليس له تأمينه، والمن عليه"(1).

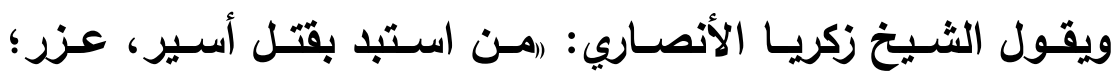

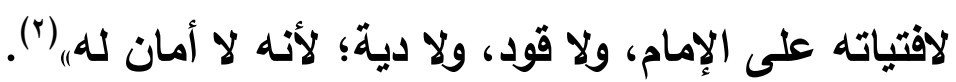

لهذا كله إذا اقتضت الضرورة، والمصلحة الشرعية اختطاف رهائن ولان

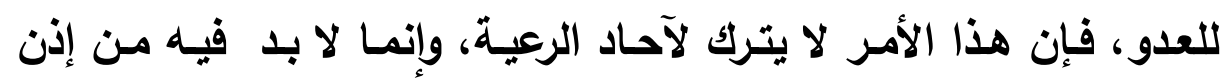

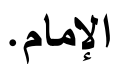

\section{المطاب الثالث: سلامة المقصد في عمطية الاختطاف.}

من الضوابط الهامة في عملية الاختطاف حسن التوجه إلى الله -

تعالى - بالإخلاص ، وهو إقراد الحق في الطاعة بالقصد، وهو النها أن يريد

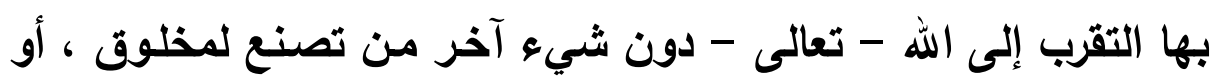

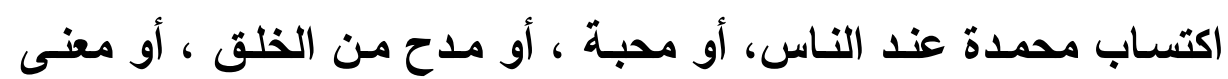
من المعاني سوى التقرب إلى الله تعالى.

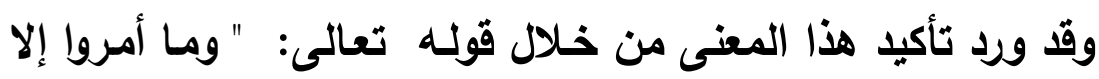

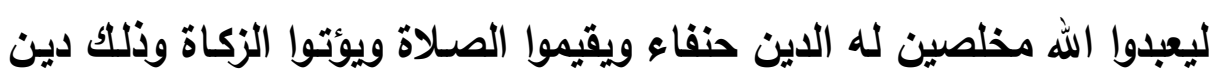
القيمة(").

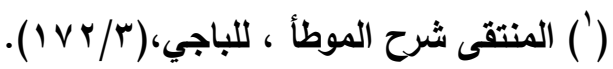

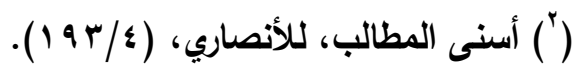

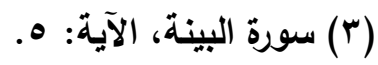


وروى أنس -رضي الله عنه- عن النبي على إخلاص الله وحده لا شريك له، وأقام الصلاة وآتى الزكاة، فارقها والله

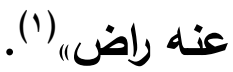

والحق أن المرع مـا دام قد أسلم وجهه لله، وأخلص نيته لـه، فِإن

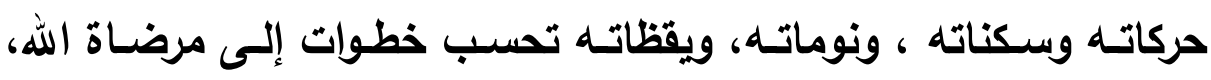
وهذا هو منهج رسول الله

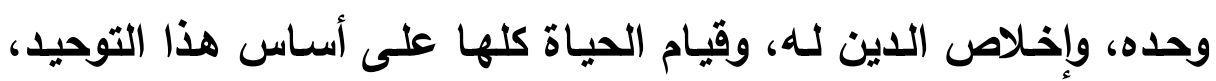

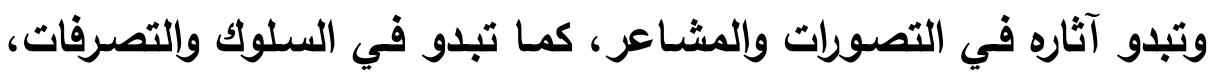

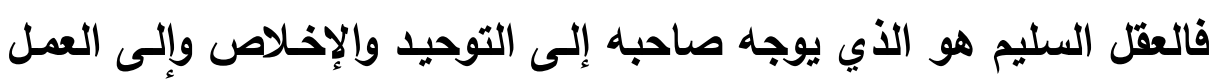
بكتاب الله ، والسنة النبوية، قال -سبحانه وتعالى - في سـورة الزمـر : "

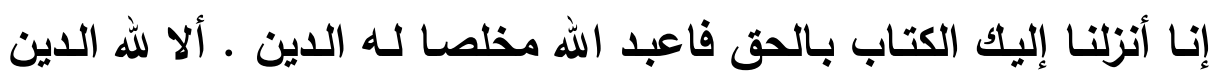

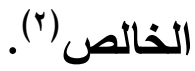
وقـال -تعالى - في السـورة نفسـها: " قل إنـي أمرت أن أعبد الله مخلصا له الداين"(").

وقال -جل شأنه- في السورة نفسها: " قل الله أعبد مخلصـا لـه

ديني"(')

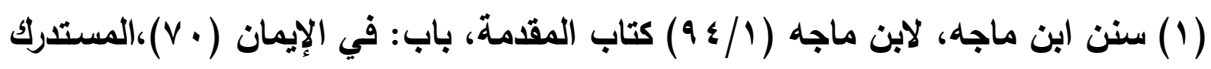

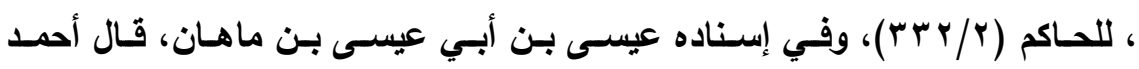

والنسائي: ليس بالقوي، وقال الفلاس: سيئ الحفظ.

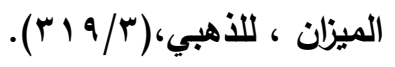

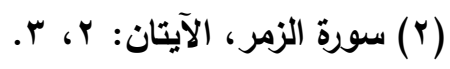

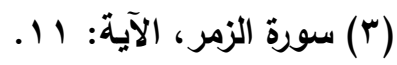


فالإخلاص يظهر مـا في العقل، والقلب من التفكير والوجدان من

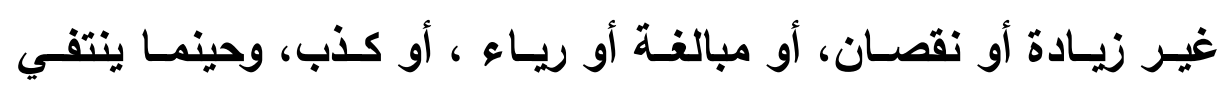
الإخلاص من الثخص تراه يغير الحقائق، ويجعل الحق باطلًا، والباطل

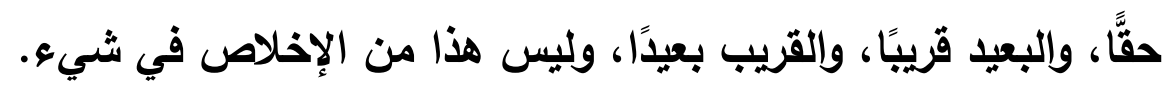

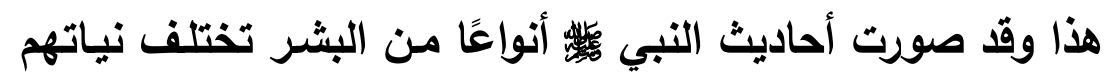

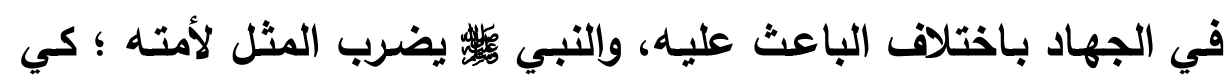

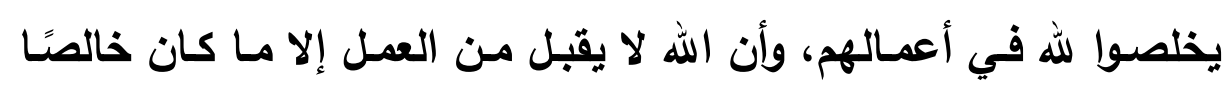
لوجها الكريم.

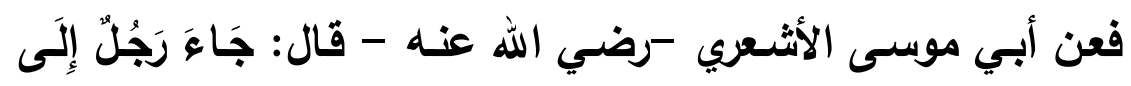
النَّبِيِّ

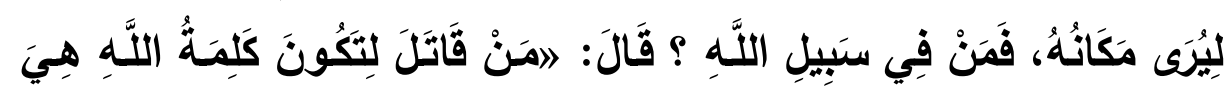

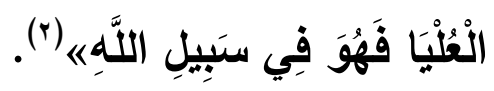

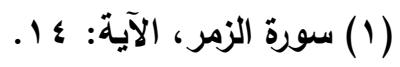

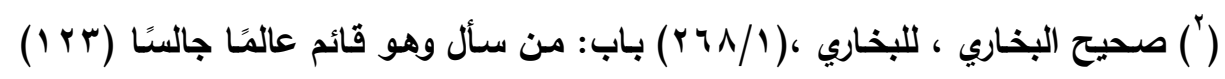

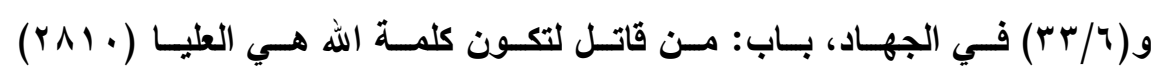

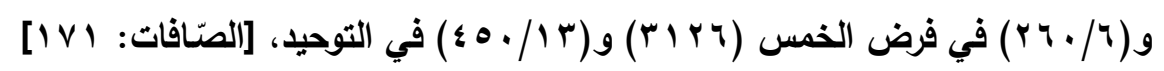

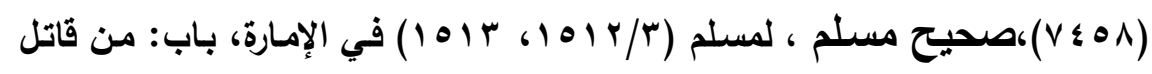

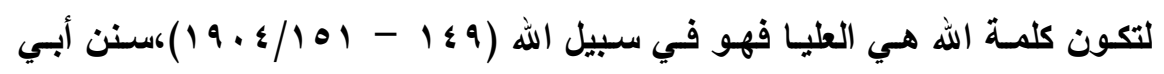
داود، لأبي داود (1/1/1) في الجهاد، بـاب: مـن قاتل لتكون كلمـة الله هـي العليا

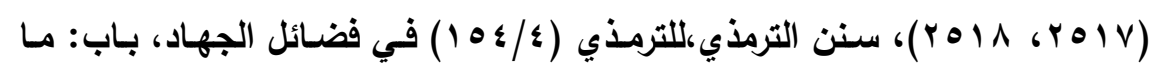

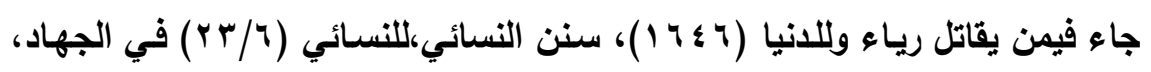

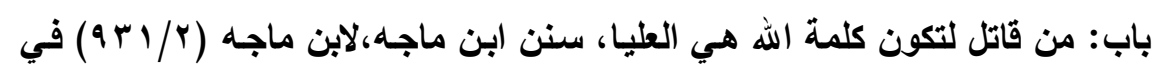


قال ابن دقيق العيد: في الحديث دليل على وجوب الإخلاص في

الجهاد، وتصريح بأن القتال للشجاعة، والحمية والرياء خارج عن ذلك('). وقـال الإمـام النـووي: فيـه بيـان أن الأعمـال إنمـا تحسب بالنيـات الصالحة، وأن الفضل الأي ورد في المجاهدين في سبيل الله يختص بمن قاتل ؛ لتكون كلمة الله هي العليا(؟).

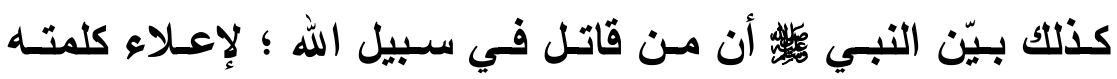
مخلصًا في نيتهـ لله - تعـالى - استحق بهـا الإخـلاص النعيم الأبـدي؛

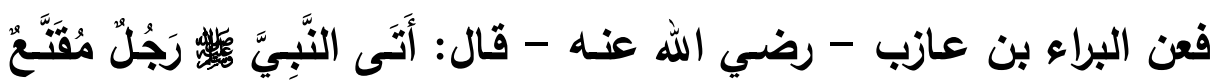

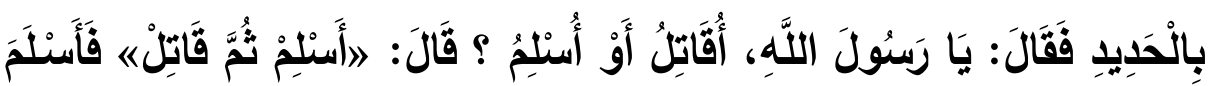

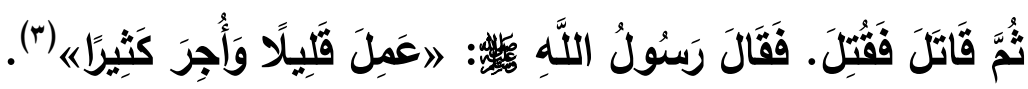

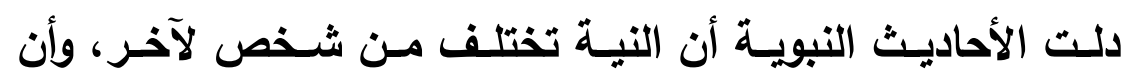
الاختطاف المقبول عند الله ما كان خالصًا لوجهه ؛؛لإعلاء كلمته ، ونصرة دينه وحمايته، وليس لأي هدف آخر من طلب السمعة والشـهرة ، وغيرها من الأهداف والغايات ، وأن النية هي المُرجِّح لثُواب الأعمال، ويناء على هن ذلك فلا بـ لمن يقدم على اختطاف فرد أو أفراد من العدو ، لا بـ من أن

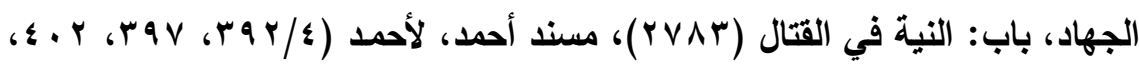

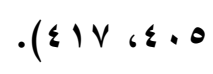

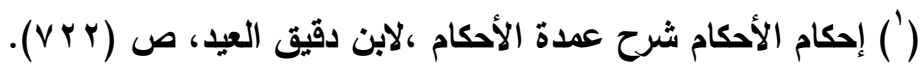

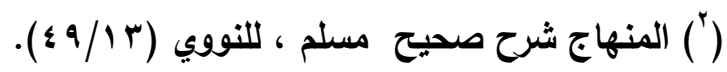

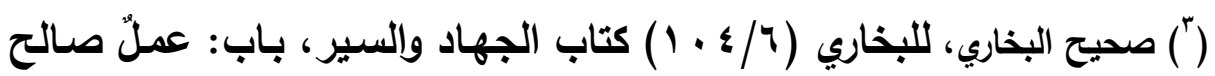

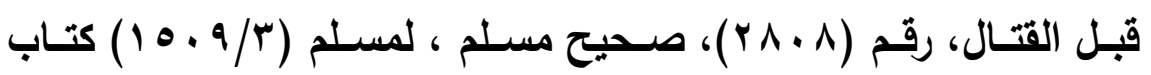

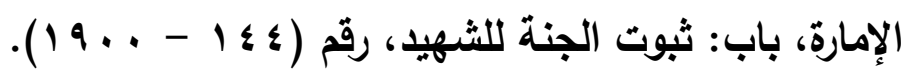


يستحضر النية الخالصة لوجه الله تعالى في عمله هذا ، وأن ينفي عن نفسه أي هدف آخر ، وإلا كان عمله مذموما ، سيما وأن طلب السمعة والثـهرة يعد ريـاء ، وهو مـا يسمى بالشرك الأصغز ، والذي يؤدي إلى هـ بطلان العمل ، بالإضافة إلى استحقاق صاحبه العقوية في الآخرة . 


\section{المبمث الثالث:}

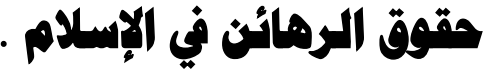

إن الثريعة الإسـلامية عنيت بخصوصية الفرد حتى ولو كان في الأسر، ومن يتأمل تراث الإسـلام في هذا الجانب ، ويطلع على مـا دونـه الفقهاء عن الأسرى ، وحقوقهم يلحظ بجلاء أن الإسدلام يجنح دائمسا وأبدا

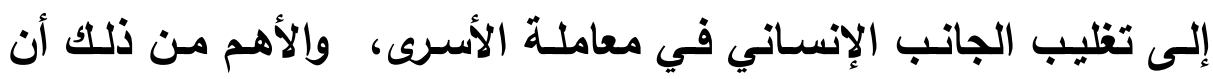
الإسلام أخضع معاملة الأسرى لنظام محكم وتشريع مدون، لا يجوز بأي حال من الأحوال تجاوزه ، أو التعدي عليه لا سبيما تحت ضغط الحالات النفسية المتوترة التي تولداها الحروب والانتصارات. لقد عامل الإسدلام الأسرى ، والرهائن معاملة إنسانية رحيمة فدعى إلى إكرامهم والإحسان إليهم، ومنحهم جملة من الحقوق ، وهي: أ -المعاملة بالرحمة والإنسانية .

وقد دل على ذلك قولـه - تعـالى -: " يـا أيها النبـي قل لمن في أيديكم من الأسرى إن يعلم الله في قلويكم خيرا يؤتكم خيرا ممـا أخذ منكم

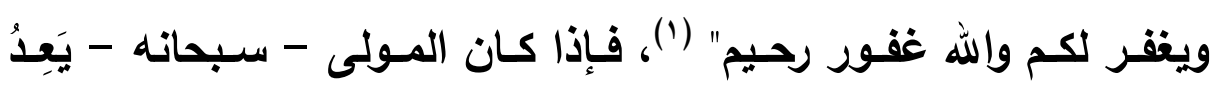
الأسرى الأين في قلويهم خيرٌ بالعفو والمغفرة، فإنَّ المسلمين لا يملكون بعد هذا إلا معاملتهم بأقصى درجة ممكنة من الرحمة والإنسانيَّة. وقد أوصى النبي

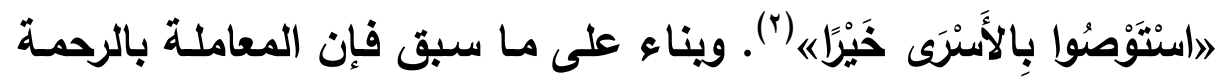

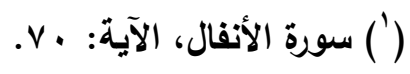

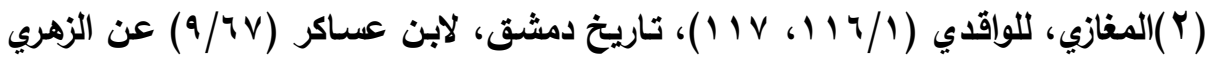


والإنسـانية كمـا تثبت للأسـرى ، فإنها تثبـ أيضـا للرهـائن ؛ لأن الكـل محبوس بيذ غيره .

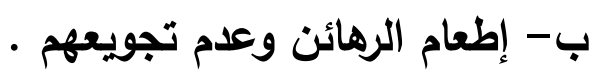

لقد قرَّر الإسلام بسماحته أنه يجب على المسلمين إطعام الأسير،

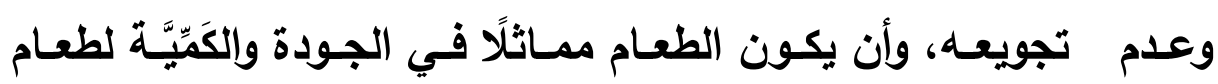

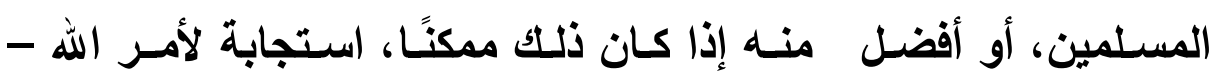
تعالى - فتال - سبحانه وتعالى -: " ويطعمون الطعام على حبه مسكينا

ويتيما وأسيرا. إنما نطعمكم لوجه الله لا نريد منكم جزاء ولا شكورا" ('). قال الحافظ ابن كثير - رحمه الله-: 》اقال ابن عباس: كان أسراهم يومئذ مشركين، ويشـه لهذا أن رسول الله أمر أصحابه يوم بـر أن يكرموا الأسارى فكانوا يقدمونهم على أنفسهم عند الغداء.... قـال مجاهــ: هـو المحبـوس؛ أي يطعمـون الطعـام لهـؤلاء وهــم

$$
\text { يشتهونه ويحبونه (r). }
$$

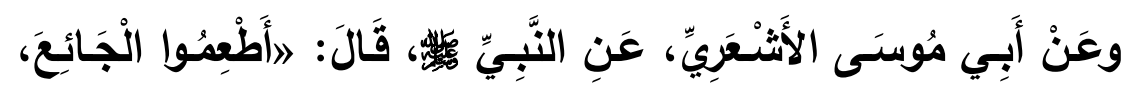

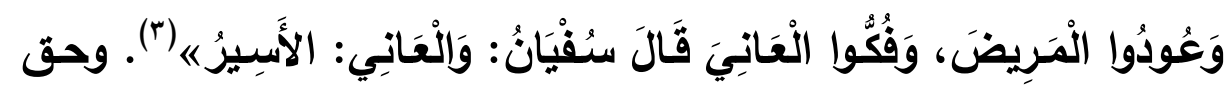

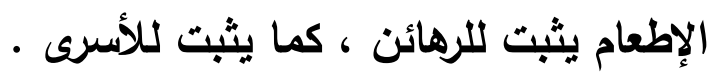

$$
\begin{aligned}
& \text { مرسلًا. } \\
& \text { (') سورة الإنسان، الآيتان ^، } 9 .
\end{aligned}
$$

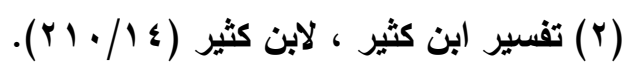

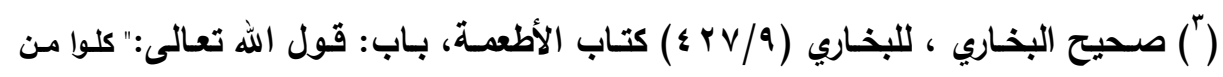

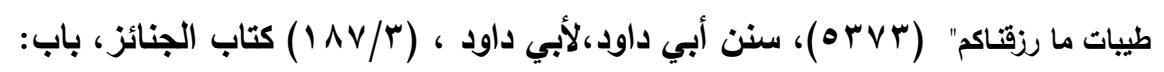

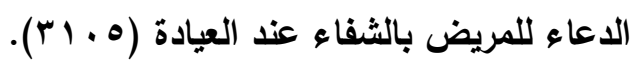




$$
\text { ج- علم جواز تعذيب الرهائن. }
$$

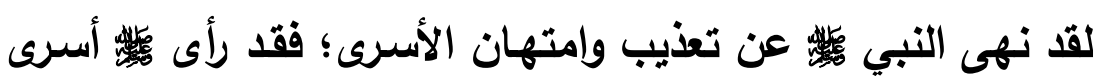
يهود بني قُرَيْة موقوفين في العراء في ظهيرة يوم قائظ، فقال مخاطِبًا

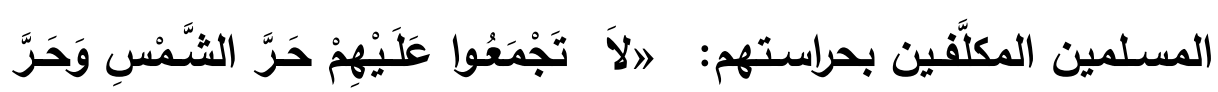

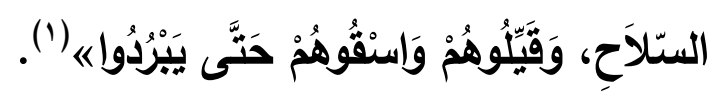

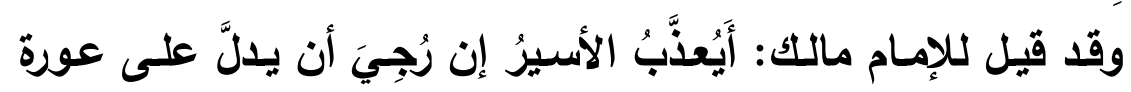

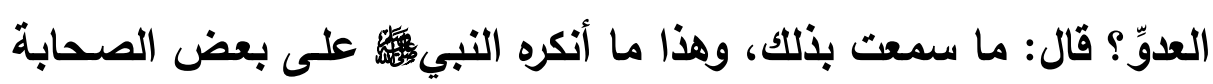

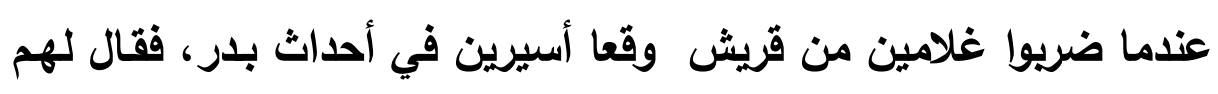

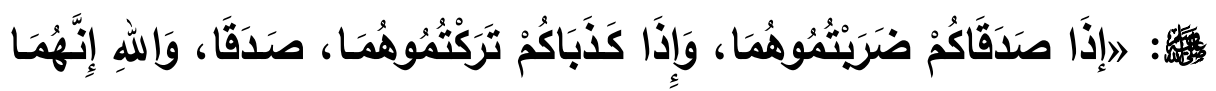

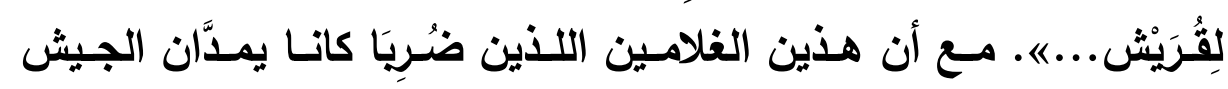

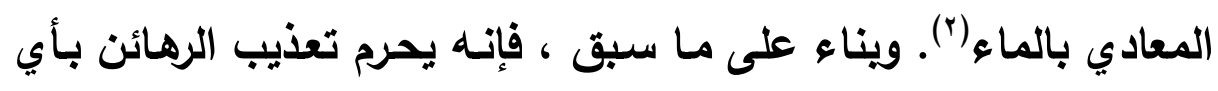

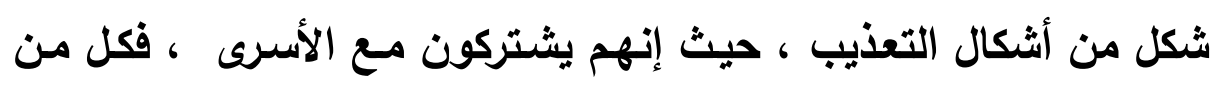

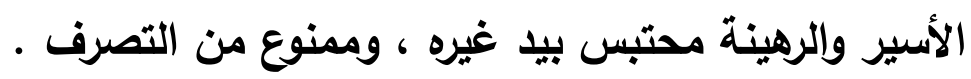
د- تحريم التمثيل بالأسرى ، والرهائن.

لقد حرم الإسلام التمثيل بالأسرى ، وعند ، ولخير الإمسام القتل يكتفي

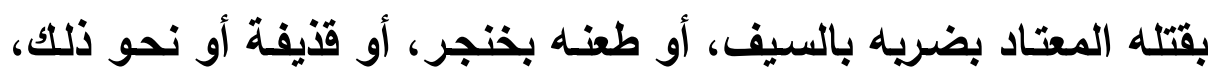

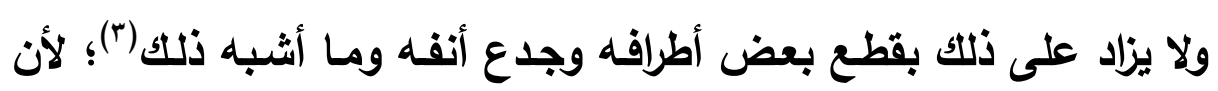
النبي

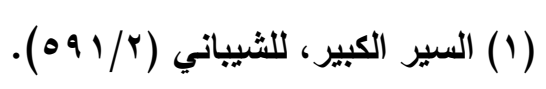

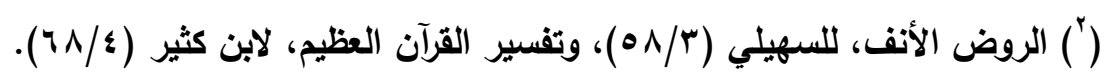

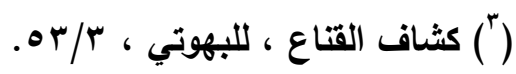




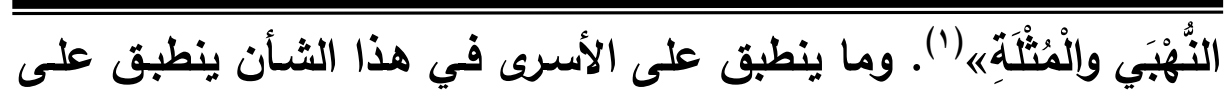
الرهائن ، وذلك فيما يتعلق بتحريم التمثيل بهم •

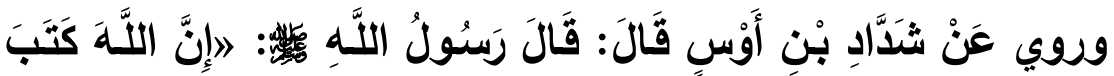

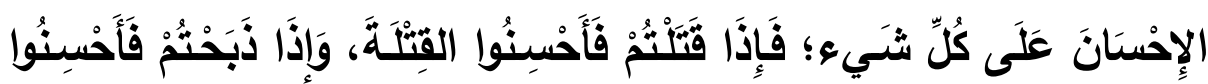

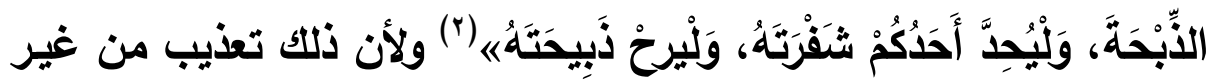
فائدة.

ولقد وصل الأمر إلى أبعد من ذلك؛ فعندما رأى التبي قريظة في الشمس نهى النبـي

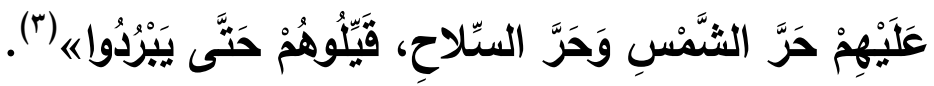
وعلى هذا فيعامل المختطف معاملـة الأسير على النهج الذي ورد في الكتاب والسنة ؛ لما بينهم من اشتراك من حيث كونهم محبوسين في يد غيرهم • والله أعلم. - اب.

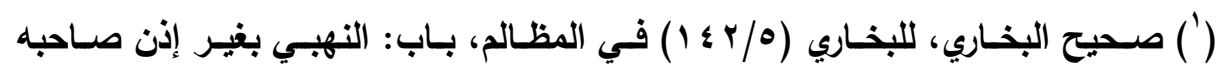

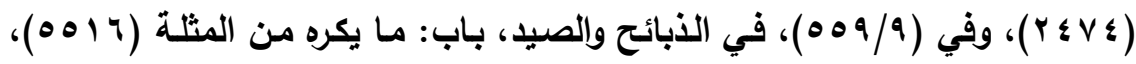

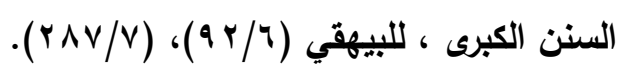

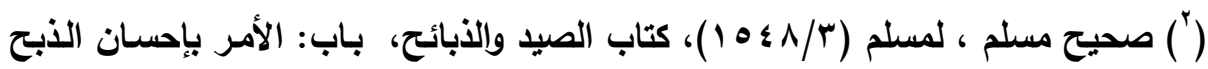

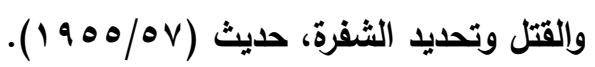

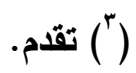




\section{الخاتمة}

وفي ختام البحث، فإنه يمكنتي القول بأن هناك عددًا من النتائج تم التوصل إليها ، والتوصيات كذلك، يمكن إبراز بعضها على لئل النحو الآتي: النتائج:

1- لـم يـرد تعريف محدد لـدى الفقهاء للخطف، وذلك لوضسوح

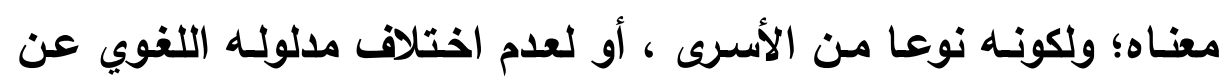
الاصطلاحي. ץ- أثبت البحتث بعضـاً مـن الـوافع التـي أدت إلى جـواز عمليـة الاختطاف ومنها: أ -إرهاب العدو ومنعه من العدوان ، أو التمادي فيه.

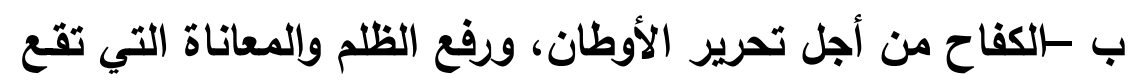
على الثعوب والأفراد والجماعات؛ كوسيلة من وسائل الاستنكار .

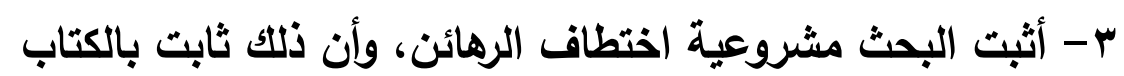

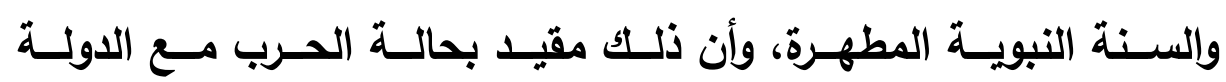
الإسنلامية.

ع - أثبت البحث أن اثتتراط تحقق العدوان، وعلم ولي الأمر بعملية

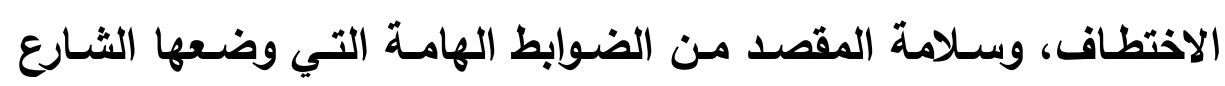
لجواز عملية الاختطاف.

ه- أن الإسلام ضمن للرهائن جملة من الحقوق لافئل البـ من أدائها

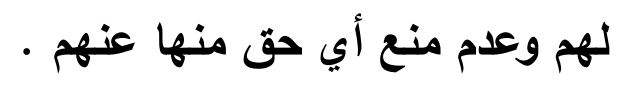
التوصيات : 
بعد الانتهاء من كتابة البحث يوصي الباحث بالتوصيات الآتية :

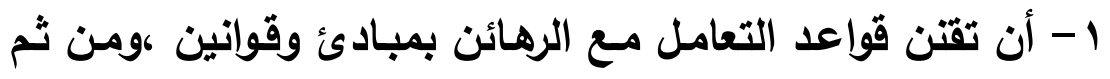
تجمع في مصنف واحد خاص بها ؛ حنى يتسنى الاطلاع عليها لطلاب العلم ، ولكل من له اهتمام في هذا المجال .

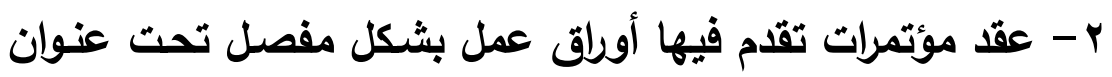
:" أحكام التعامل مع الرهائن.

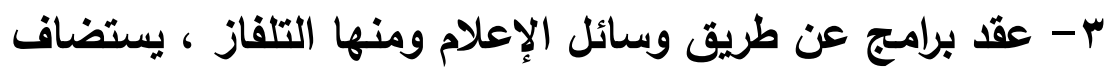
فيها بعض المختصين من ذوي المعرفة من العلماء الأثبات ، لتوضيح

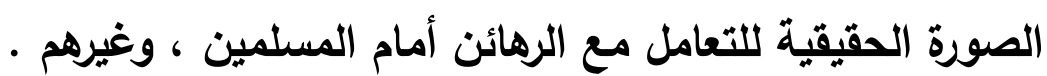
والله ولي التوفيق. 


\section{المسادر والمراجع}

- إحكام الأحكام شرح عمدة الأحكام ، لابن دقيق العيد،( د ـ ط) ،

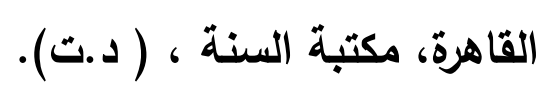

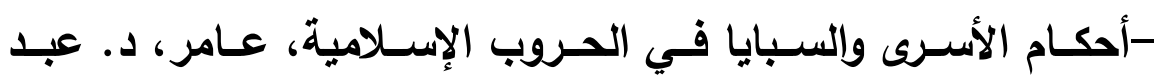

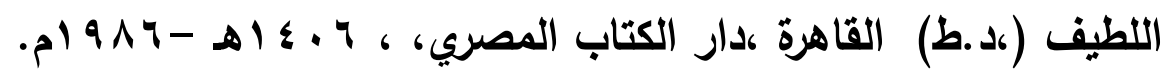

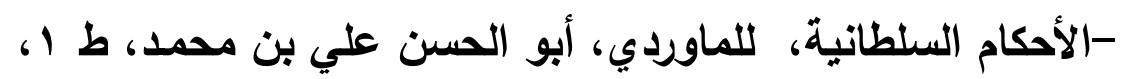

$$
\text { بيروت، دار الكتب العلمية، ،(د.ت). }
$$

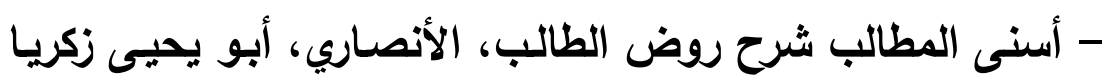

، (د.ط) القاهرة،المكتبة الإسلامية، دار الكتاب الإسلاهي، (د د.ت) .

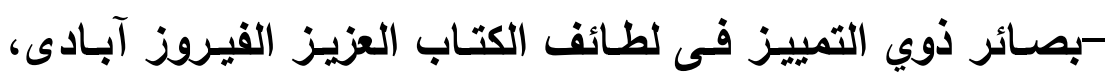

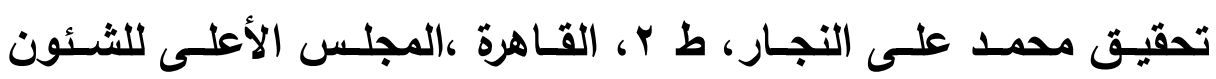

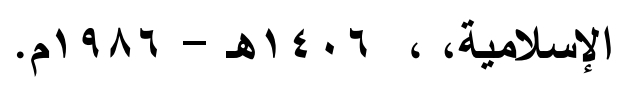

-تاريخ مدينة دمشثق وذكر فضلها وتسمية من حلها من الأماثل،

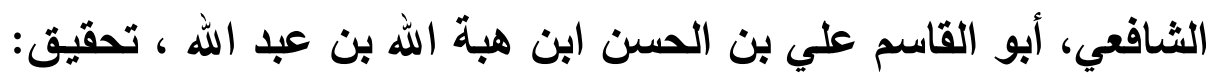

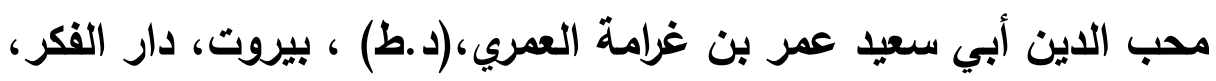

$$
\text { م990، }
$$

- تسليط الأضواء على مـا وقع في الجهاد من أخطاء، حافظ، د.

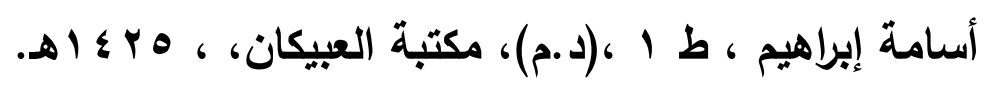

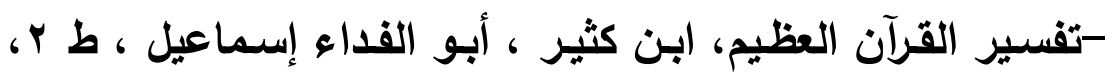

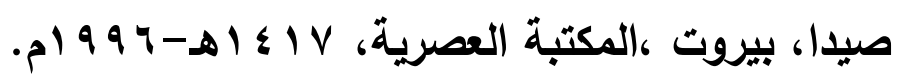


-الجامع الصحيح 》انن الترمذيه ،الترمذي ، أبو عيسى محمد

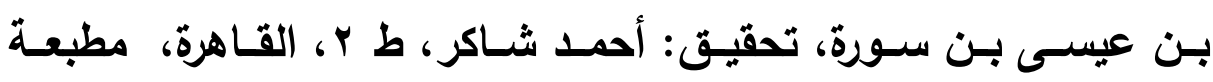

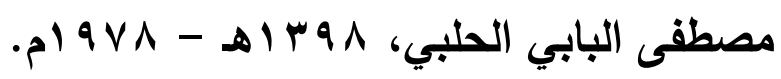

-الجـامع لأحكام القرآن، القرطبي، أبو عبــ الله محمد بـ أحمــ

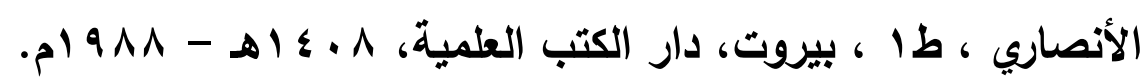

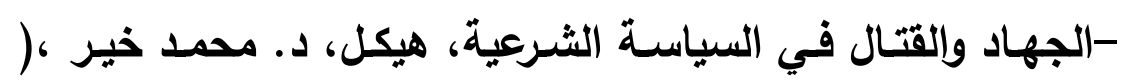

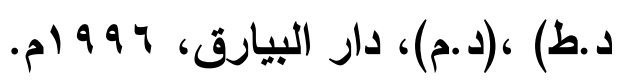

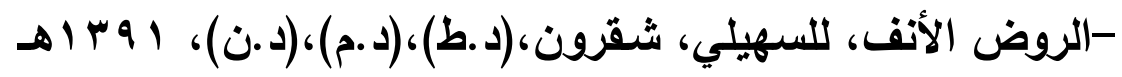
$.019 \times 1-$

-سنن ابن ماجـه، ابن ماجـه، محمد بـن يزيـا القزوينـي، تحقيق محمـد فـؤاد عبد البـاقي، ط ا، القـاهرة، دار الحـديث ، ، 19 1 ؛ اهـ . 1991

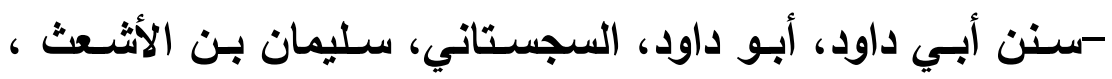
تحقيق محمد محي الدين عبد الحميد، (د.ط) ،(د.م)، دار الفكر،( د.ت). -سنن الدارقطني، الدارقطني، الإمام على بن عمر ويذيله التعليق

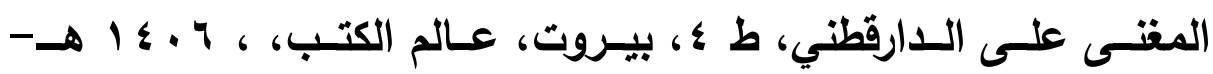
. 1917

-السنن الكبرى، البيهةي، أبو بكر أحمد بن الحسن بن علي ،

$$
\text { (د.ط)، بيروث ،دار الفكر، ، } 9 \text { ، ام. }
$$

-سـنن النسـائي، النسـائي، أبـو عبــ الرحمن أحمــ بـن شـيب ،

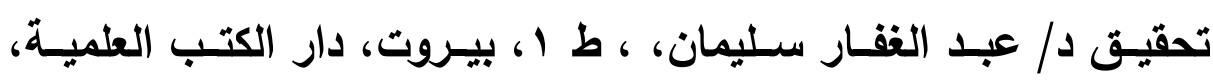

$$
\text { . } 1991-81 \leq 11
$$


-شرح السير الكبير، السرخسي، محد بن أحمد بن أبسي سهل ، (د.ط)، (د.م)، الشركة الشرقية للإعلانات، (د د.ت) . - شرح صحيح مسلم ، النووي، يحيى بن شرف ، طس، القاهرة، دار الحديث، ، 199-19 19 19

-صـيح البخـاري، البخـاري، أبـو عبد الله محمد بـن إسـماعيل ، تحقيق: مصطفى ديب البغا، ط ب، بيروت، دار ابن كثير، ، ب + ع اهـ - $19 \wedge \mathrm{V}$

-صحيح مسلم، القثبيري،أبو الحسين مسلم بن الحجاج ، (د.ط)، بيروت، دار إحياء التراث العربي، ، (د.ت) .

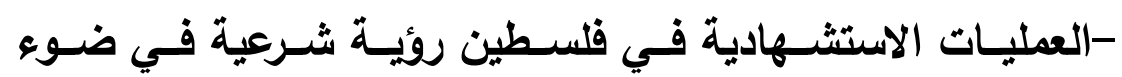
المعطيات الواقعية، جمعه، منير أحمد، ( د.ط) ، ( د.م)، (د.ن)، (د.ت لد

-القاموس المحيط، الفيروزآبـادي ، محمد بـن يعقوب ، تحقيق: على محمد البجاوى، ومحمد أبو الفضل إبراهيم، ط r ب، بيروت ،المكتبة ،

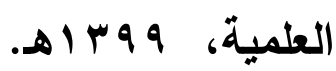

-قضايا فقهية في العلاقات الدولية حال الحرب، أبو غدة د. حسن

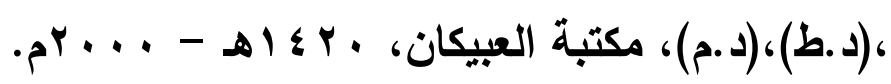

-كشـاف القتـاع ، البهوتي، منصور بن يونس ، (د.ط)، بيروت -

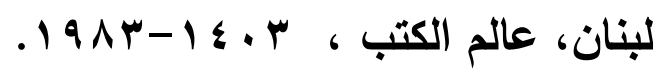

-لسـان العرب،ابن منظور، محمـد بن مكرم بن منظور الأفريقي المصري، ط 1 ، بيروت، دار صادر ،(د.ت). 
-مائة سؤال عن الإسـلام،الغزالي، الثيخ محمد، طا، القاهرة، دار

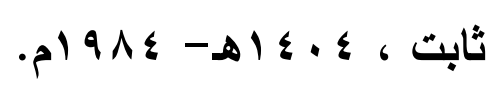

-المستدرك على الصحيحين،الحاكم ، الحافظ أبي عبد الله محمد

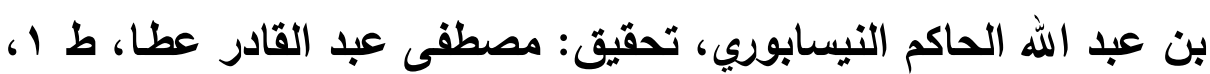

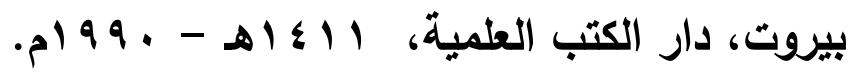
-مسند الإمام، أحمد بن حنبل، تحقيق: شعيب الأرناؤوط، وعادل

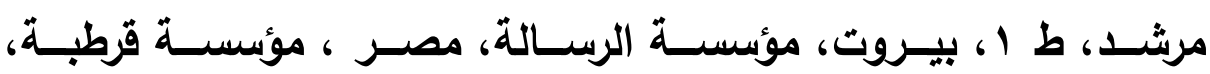

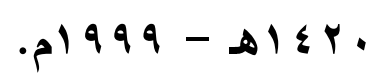

-المصباح المنير في غريب الثـرح الكبير، الفيومي، أحمد بـن

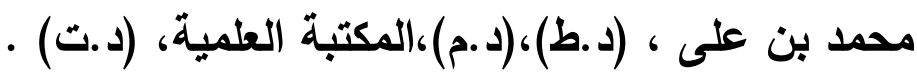

-معجم المؤلفين ، كحالة ،عمر ،(د.ط)، بيروت- لبنان، دار إحياء

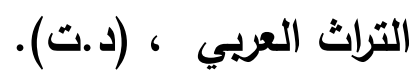

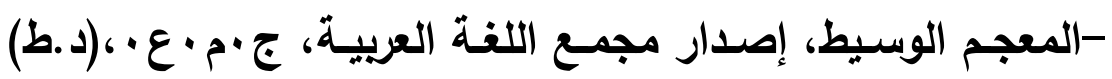

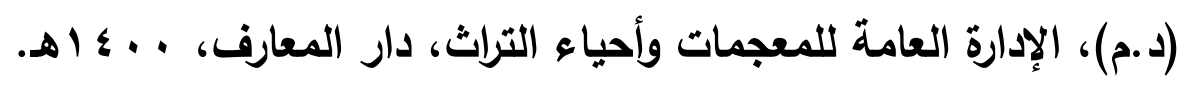

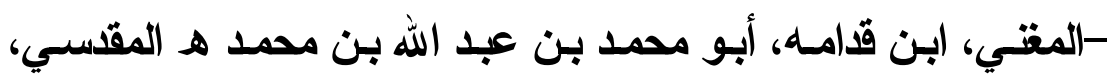

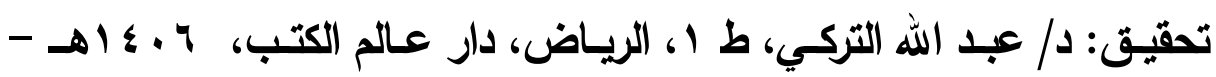
. 9194

-المنتقى شـرح الموطأ، الباجي،أبو الوليد ، (د.ط)، القاهرة ،دار

$$
\text { الكتب العربية، (د.ت). }
$$

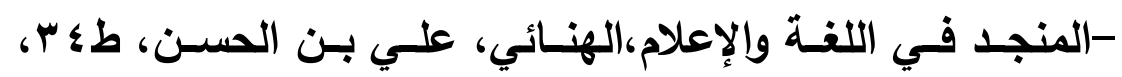

$$
\text { بيروت، دار المشرق ،(د.ت). }
$$


-منهاج السنة النبوية في نقض كلام الثيعة القرية،، ابن تيمية،

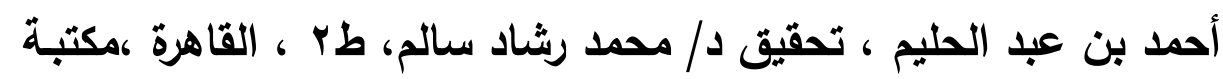

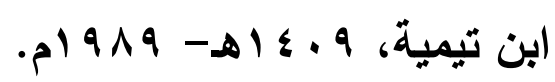

-مواهب الجليل لثرح مختصر خليل، الحطَّب ، أبو الضّياء خليل

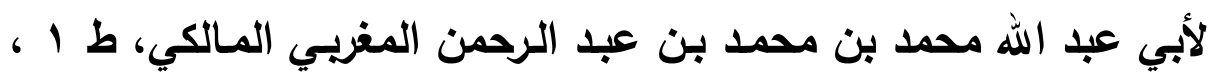

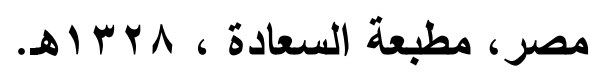

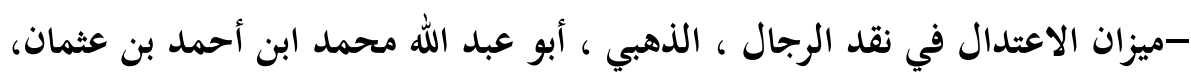

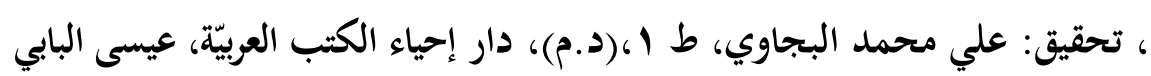

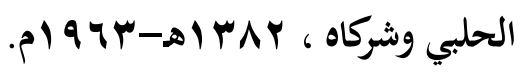


س 